OPEN ACCESS

Edited by:

Zhongjian Xie,

Central South University, China

Reviewed by:

Michael F. Holick,

Boston Medical Center, United States Melissa Orlandin Premaor

Federal University of Minas

Gerais, Brazil

*Correspondence:

Rene F. Chun

rchun@mednet.ucla.edu

Specialty section: This article was submitted to

Bone Research,

a section of the journa

Frontiers in Endocrinology

Received: 26 April 2019 Accepted: 04 October 2019

Published: 24 October 2019

Citation:

Chun RF, Shieh A, Gottlieb C, Yacoubian V, Wang J, Hewison M and Adams JS (2019) Vitamin D Binding Protein and the Biological Activity of Vitamin D. Front. Endocrinol. 10:718.

doi: 10.3389/fendo.2019.00718

\section{Vitamin D Binding Protein and the Biological Activity of Vitamin D}

\author{
Rene F. Chun ${ }^{1 *}$, Albert Shieh ${ }^{2}$, Carter Gottlieb ${ }^{1}$, Vahe Yacoubian ${ }^{1}$, Jeffrey Wang ${ }^{1}$, \\ Martin Hewison ${ }^{3}$ and John S. Adams ${ }^{1}$ \\ ${ }^{1}$ Department of Orthopaedic Surgery, David Geffen School of Medicine at UCLA, Los Angeles, CA, United States, \\ ${ }^{2}$ Department of Medicine, David Geffen School of Medicine at UCLA, Los Angeles, CA, United States, ${ }^{3}$ Institute of \\ Metabolism and Systems Research, University of Birmingham, Birmingham, United Kingdom
}

Vitamin $\mathrm{D}$ has a long-established role in bone health. In the last two decades, there has been a dramatic resurgence in research interest in vitamin $D$ due to studies that have shown its possible benefits for non-skeletal health. Underpinning the renewed interest in vitamin D was the identification of the vital role of intracrine or localized, tissue-specific, conversion of inactive pro-hormone 25-hydroxyvitamin D [25(OH)D] to active 1,25-dihydroxyvitamin $\mathrm{D}\left[1,25(\mathrm{OH})_{2} \mathrm{D}\right]$. This intracrine mechanism is the likely driving force behind vitamin $D$ action resulting in positive effects on human health. To fully capture the effect of this localized, tissue-specific conversion to $1,25(\mathrm{OH})_{2} \mathrm{D}$, adequate $25(\mathrm{OH}) \mathrm{D}$ would be required. As such, low serum concentrations of $25(\mathrm{OH}) \mathrm{D}$ would compromise intracrine generation of $1,25(\mathrm{OH})_{2} \mathrm{D}$ within target tissues. Consistent with this is the observation that all adverse human health consequences of vitamin $D$ deficiency are associated with a low serum $25(\mathrm{OH}) \mathrm{D}$ level and not with low $1,25(\mathrm{OH})_{2} \mathrm{D}$ concentrations. Thus, clinical investigators have sought to define what concentration of serum 25(OH)D constitutes adequate vitamin D status. However, since 25(OH)D is transported in serum bound primarily to vitamin $D$ binding protein (DBP) and secondarily to albumin, is the total $25(\mathrm{OH}) \mathrm{D}$ (bound plus free) or the unbound free $25(\mathrm{OH}) \mathrm{D}$ the crucial determinant of the non-classical actions of vitamin D? While DBP-bound-25(OH)D is important for renal handling of $25(\mathrm{OH}) \mathrm{D}$ and endocrine synthesis of $1,25(\mathrm{OH})_{2} \mathrm{D}$, how does DBP impact extra-renal synthesis of $1,25(\mathrm{OH})_{2} \mathrm{D}$ and subsequent $1,25(\mathrm{OH})_{2} \mathrm{D}$ actions? Are their pathophysiological contexts where total $25(\mathrm{OH}) \mathrm{D}$ and free $25(\mathrm{OH}) \mathrm{D}$ would diverge in value as a marker of vitamin $D$ status? This review aims to introduce and discuss the concept of free $25(\mathrm{OH}) \mathrm{D}$, the molecular biology and biochemistry of vitamin $\mathrm{D}$ and DBP that provides the context for free $25(\mathrm{OH}) \mathrm{D}$, and surveys in vitro, animal, and human studies taking free $25(\mathrm{OH}) \mathrm{D}$ into consideration.

Keywords: vitamin D, free vitamin D, bone, immunology, DBP, CYP27B1, VDR

\section{INTRODUCTION}

The benefits of vitamin D for mineral homeostasis and bone health are well-established. Deficiency of vitamin D, rickets in children and osteomalacia in adults, can be treated or prevented with oral supplements of vitamin D. Despite promising pre-clinical observations and vitamin D-deficiency association studies, the impact of vitamin $\mathrm{D}$ on other aspects of human health such as common 
cancers, cardiovascular disease, type 2 diabetes obesity, autoimmune disorders, and infectious disease remains controversial (1-5). Randomized, controlled supplementation trials are required to better define the extra-skeletal roles of vitamin D. However, these trials are complicated by two unanswered questions: (1) what is the best marker of vitamin D status and (2) what constitutes a level that is sufficient to promote the health benefits of vitamin $\mathrm{D}$ ?

\section{ENDOCRINE VITAMIN D METABOLISM AND ACTION}

The name "vitamin D" in this review refers to a collection of secosterol molecules detectable in the serum of vertebrates (left panel, Figure 1). Briefly, cholecalciferol or vitamin D3 (vitamin D) results from the ultraviolet B (UVB; 290-315 nm)mediated photolytic-conversion of 7-dehydrocholesterol (DHC) in skin (6-8). Vitamin D can also be obtained from (i) food, principally from fortified dairy and juice products, (ii) consumption of fresh caught fish (e.g., salmon) (9), and (iii) oral vitamin D supplements. Vitamin D2 (ergocalciferol) is naturally found in fungi (e.g., mushrooms) and sometimes used in food fortification and supplementation regimes. Regardless vitamin D2 proceeds through the same modifications as described for vitamin D3 below.

Once in the general circulation vitamin $\mathrm{D}$ is bound to its serum carrier, vitamin D binding protein (DBP) and to a lesser extent albumin $(10,11)$, and is subject to a first hydroxylation step by vitamin D substrate-dependent 25-hydroxylase [CYP2R1 (12) and possibly a yet unidentified hydroxylase(s) (13)] in the liver resulting in 25-hydroxyvitamin D $(25(\mathrm{OH}) \mathrm{D})$. Very little $25(\mathrm{OH}) \mathrm{D}(\sim 5 \%)$ is secreted in to the bile (14). Rather, the bulk of $25(\mathrm{OH}) \mathrm{D}$ re-enters the circulation, once again bound to either DBP or albumin for endocrine transport to target tissues. DBP- and albumin-bound 25(OH)D in urine is reclaimed by tubular epithelial cells in the kidney (15). Here internalized $25(\mathrm{OH}) \mathrm{D}$ is freed from its carrier protein(s), becoming substrate for (i) the low capacity 25-hydroxyvitamin D-1-alpha-hydroxylase (CYP27B1) and production of the active, hormonal form of vitamin D, 1,25-dihydroxyvitamin D $\left(1,25(\mathrm{OH})_{2} \mathrm{D}\right)$ or (ii) the high calpacity 25 -dihydroxyvitamin D24 hyxdoxylase (CYP24A1) to form the largely non-biologically active metabolites 24,25-dihydroxyvitamin $\mathrm{D}\left(24,25(\mathrm{OH})_{2} \mathrm{D}\right)$ and 1,24,25-trihydroxyvitamin $\mathrm{D}$, respectively (16). The various hydoxylated forms gain access to the general circulation bound to DBP or albumin. Rheostatic endocrine control over the reciprocal production of 1- and 24-hydroxylated vitamin $\mathrm{D}$ metabolites is exerted by parathyroid hormone and FGF23. Parathyroid hormone increases activity of CYP27B1hydroxylase $(17,18)$, decreases product output by CYP24A1 $(19,20)$; thus, increases the "activation" quotient of product $1,25(\mathrm{OH})_{2} \mathrm{D}$ :substrate $25(\mathrm{OH}) \mathrm{D}$ in the serum. On the other hand, FGF-23 blunts CYP27B1 activity (21) and promotes CYP24A1 activity; thus, decreases the $1,25(\mathrm{OH})_{2} \mathrm{D}: 25(\mathrm{OH}) \mathrm{D}$ activation quotient and increases the $24,25(\mathrm{OH})_{2} \mathrm{D}: 25(\mathrm{OH}) \mathrm{D}$ inactivation quotient $(22,23)$.
As noted above, $1,25(\mathrm{OH})_{2} \mathrm{D}$ can be chaperoned in an endocrine mode to potential target tissues that employ serum bound, extracellular $1,25(\mathrm{OH})_{2} \mathrm{D}$ as a specific ligand for transactivation of the vitamin $\mathrm{D}$ receptor (VDR) in the target cell driving $1,25(\mathrm{OH})_{2} \mathrm{D}-\mathrm{VDR}$ directed differential gene expression (24). A major caveat in the concept of direct endocrine action of $1,25(\mathrm{OH})_{2} \mathrm{D}$ is the fact all adverse physiological consequences of vitamin $\mathrm{D}$ deficiency in humans are associated with a low serum $25(\mathrm{OH}) \mathrm{D}$, not a low $1,25(\mathrm{OH})_{2} \mathrm{D}$ level [Table 1; (25)]. In fact, in the basal state, before treatment to raise 25D levels, subjects with low serum $25 \mathrm{D}$ often have serum $1,25 \mathrm{D}$ levels that are relatively elevated as a consequence of compensatory secondary hyperparathyroidism. In this instance the increase in the host's circulating concentration of PTH drives an increase in renal $1,25 \mathrm{D}$ production. This suggests that $25 \mathrm{D}$ deficiency in the serum is a cause for "endocrine resistance" to circulating levels of the $1,25 \mathrm{D}$ hormone at the level of the gut. After vitamin D restoration treatment with return of $25 \mathrm{D}$ balance to normal and resolution of secondary hyperparathyroidism, there is an increase in intestinal calcium absorption even though there is a relative decrease, or no change in the circulating serum $1,25 \mathrm{D}$ level. This suggests that there may be local conversion of $25 \mathrm{D}$ to $1,25 \mathrm{D}$ in the gut outside of the serum compartment that is driving intestinal calcium absorption and/or that only measuring the total amount of vitamin $\mathrm{D}$ metabolite(s) in the serum, may be an inadequate biomarker of response to restoration of $25 \mathrm{D}$ levels in the blood to normal.

\section{LOCAL VITAMIN D METABOLISM AND ACTION}

In non-renal tissues, the CYP27B1 converts $25(\mathrm{OH}) \mathrm{D}$ to $1,25(\mathrm{OH})_{2} \mathrm{D}$ for local usage in paracrine, autocrine, and intracrine regulated activities (26). Perhaps the most relevant physiological/pathophysiological example of these events (e.g., those confined to the local tissue microenvironment outside of circulating serum compartment) are the human granuloma forming diseases like sarcoidosis and tuberculosis (27). In these disease states, cells of the innate immune response, principally macrophages, express the same metabolic machinery to synthesize $1,25(\mathrm{OH})_{2} \mathrm{D}$ intracellularly when presented with a CYP27B1 activating signal and with sufficient $25(\mathrm{OH}) \mathrm{D}$ in the extracellular space to serve as substrate for the CPY27B1. When the extracellular concentration of $25(\mathrm{OH}) \mathrm{D}$ falls below the equivalent of $\sim 20 \mathrm{ng} \cdot \mathrm{mL}^{-1}$ or $50 \mathrm{nM}$, the intracrine production of $1,25(\mathrm{OH})_{2} \mathrm{D}$ via the CYP27B1-hydroxylase becomes limiting; unlike the renal CYP27B1, the enzyme in the macrophage is highly substrate-drive (28). Taking the human granulomaforming, macrophage dominant infectious disease tuberculosis (TB) as an example, in the face of deficient extracellular substrate $25(\mathrm{OH}) \mathrm{D}$ the macrophage CYP27B1 is unable to generate enough active $1,25(\mathrm{OH})_{2} \mathrm{D}$ metabolite to effectively ligand sufficient VDR in that cell to promote expression of vitamin $\mathrm{D}$-dependent antimicrobial genes $(29,30)$. The end result is failure of the macrophage to mount an effective autophagyrelated, vesicular killing response to ingested Mycobacterium 


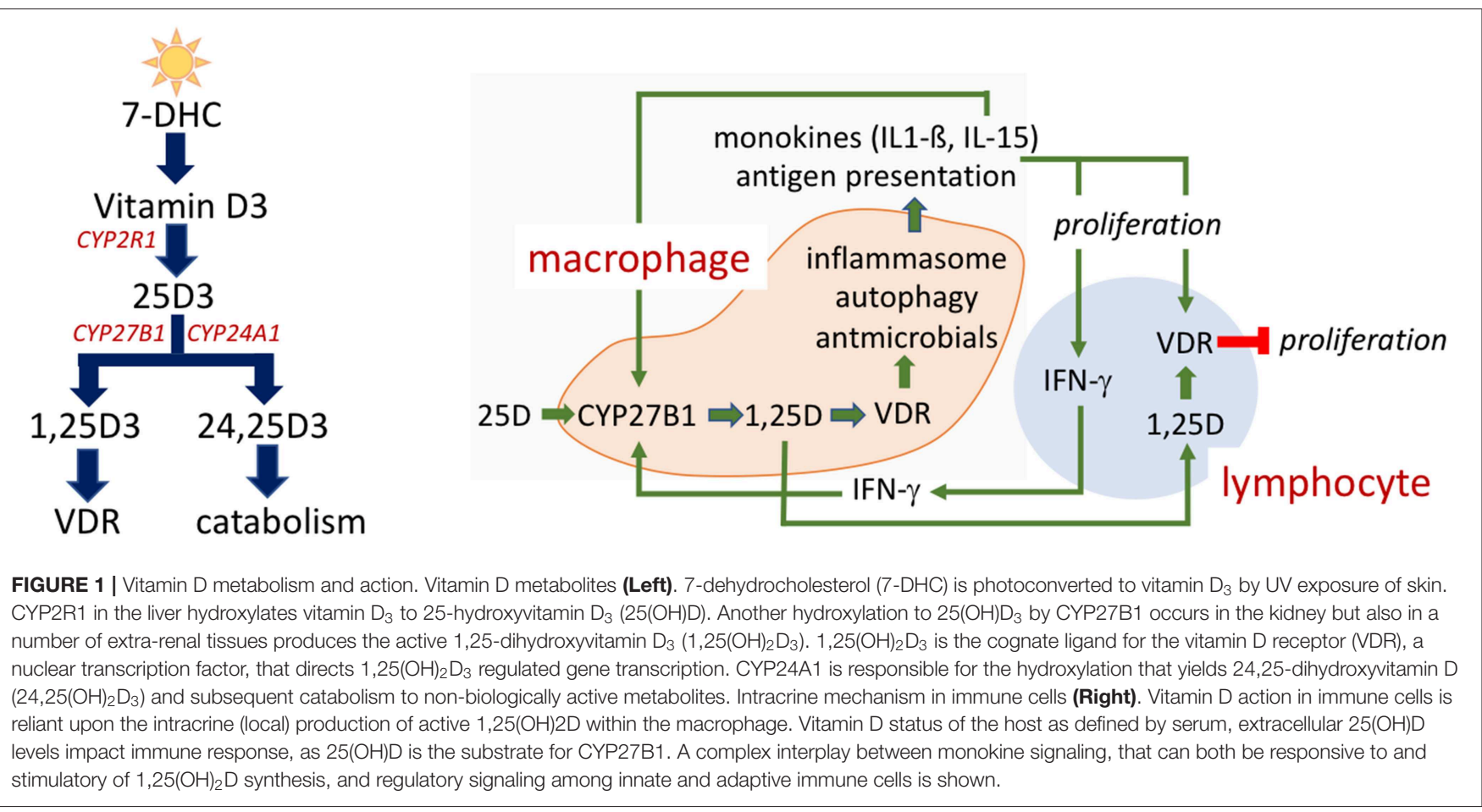

TABLE 1 | Vitamin D and human health.

\section{Adverse health outcomes significantly associated with low serum} 25(OH)D level

\section{Low bone density}

Hip fractures

Non-vertebral fractures

Heart attack

Hypertension

Stroke

Neurocognitive dysfunction

Proximal muscle weakness

Autoimmune diseases

Numerous health conditions have been associated with low total serum levels of 25(OH)D and are listed in the table. Conditions pertaining to bone health are indicated in blue. Table is based on reviews by Rosen et al. (2) and Rosen and Taylor (4).

tuberculosis $(M . t b)(31,32)$. In vitro this failure can be rescued in a $25(\mathrm{OH}) \mathrm{D}$ concentration-dependent fashion by exchanging vitamin $\mathrm{D}$ deficient human serum with vitamin $\mathrm{D}$ sufficient serum (>30 ng.mL-1 or $75 \mathrm{nM}$ ); in other words, rescue of the macrophage innate immune is achieved by conditioning activated macrophages ex vivo in serum from the same host after treatment of the host with vitamin $\mathrm{D}$ in vivo (30). Demonstrating successful rescue from $25(\mathrm{OH}) \mathrm{D}$ deficiency in vivo in humans exposed to or in the very early phases of infection with $M$. $t b$. would support the value of $25(\mathrm{OH}) \mathrm{D}$-driven innate immune competence in prevention and use as adjunctive therapy early in the course of this disease (33).

The local antimicrobial capacity of the macrophage is subject to intracrine, autocrine, and paracrine feedforward and feedback immune regulatory circuits. This regulatory network is depicted schematically in the right panel of Figure 1. Stimulation of the Toll-like receptor signaling pathway by pathogen-associated molecular pattern (PAMP) molecules induces expression of CYP27B1 and VDR as well as of monokines (e.g., IL-15 and IL-1 $\beta$ ). In an autocrine mode, these two monokines act to amplify expression of the CYP27B1 and $1,25(\mathrm{OH})_{2} \mathrm{D}$-VDR-directed generation of antimicrobial peptides (34). In a paracrine fashion IL- $1 \beta$ mobilizes and activates cells of the adaptive immune response (35-37). Activation of the Th1 subset of "helper" lymphocytes promotes: (1) production of IFN- $\gamma$, the most potent known stimulator of the macrophage CYP27B1-hydroxylase (38); and (2) induction of expression of the VDR in adaptive immune response cells $(39,40)$. When IFN- $\gamma$-driven production of $1,25(\mathrm{OH})_{2} \mathrm{D}$ in the macrophage is robust enough to allow escape of the active vitamin $\mathrm{D}$ metabolite into the local, pericellular inflammatory microenvironment, this $1,25(\mathrm{OH})_{2} \mathrm{D}$ is sufficient to drive VDRdependent gene expression in activated lymphocytes such as inhibiting proliferation of those lymphocytes. As such, the predominant paracrine action of $1,25(\mathrm{OH})_{2} \mathrm{D}$ in this setting is to modify the adaptive immune response (41) and turn down IFN- $\gamma$ and macrophage CYP27B1 gene expression, preventing a potential overzealous adaptive (auto)immune response harmful to the host. Therefore, 25(OH)D "sufficiency" in the serum of the host appears to be paramount in providing the optimal IFN$\gamma$-mediated feedback control on $1,25(\mathrm{OH})_{2} \mathrm{D}$ synthesis by the macrophage and appropriate antimicrobial response to ingested microbes. For example, failure of this normal feedback control in disseminated infection with $M$. $t b$. may result in escape of $1,25(\mathrm{OH})_{2} \mathrm{D}$ from the local immune microenvironment into the serum tuberculosis, resulting in a form of endocrine-acting 
“ $1,25(\mathrm{OH})_{2} \mathrm{D}$ intoxication" and life-threatening hypercalcemia. This form of extra-renal $1,25(\mathrm{OH})_{2} \mathrm{D}$ intoxication can occur in certain granuloma-forming diseases such as tuberculosis (where pathogen is known) and sarcoidosis (where pathogen is unknown).

These scenarios indicate that the serum level of bioavailable $25(\mathrm{OH}) \mathrm{D}$ to macrophages is a key determinant of normal/abnormal physiological control of innate and adaptive immunity in the host with low serum 25(OH)D levels. Cell and molecular biology experiments have established co-existent expression of the CYP27B1 and VDR in the same cell (Table 2). This observation makes all of these cell-types potential candidates for intracrine metabolism and action of $1,25(\mathrm{OH})_{2} \mathrm{D}$ generated from $25(\mathrm{OH}) \mathrm{D}$ available to that cell from its extracellular microenvironment in vivo. Beyond tuberculosis just discussed, many human diseases are associated with "low" serum 25(OH)D levels compared to matched controls without the disease (Table 1). In cardiovascular disease, the leading cause of mortality in the US, mortality is inversely related to serum $25(\mathrm{OH}) \mathrm{D}<20 \mathrm{ng} / \mathrm{ml}(42,43)$, though this is disputed (44). All of these disease states are associated with altered host immunity. Perhaps this is the common link to adverse outcomes in this otherwise diverse set of disorders.

\section{DEFINING VITAMIN D STATUS}

The total serum $25(\mathrm{OH}) \mathrm{D}$ level (the sum of $25(\mathrm{OH}) \mathrm{D}$ that is bound to carrier proteins and is free in the circulation) is the currently accepted marker of choice for defining vitamin $\mathrm{D}$ status in any given individual. Its preferential use is based on (i) analysis of the existing body of clinical research, (ii) assay advances that confer easy and accurate measurements and (iii) the fact that it is the most abundant and stable of the various vitamin $\mathrm{D}$ metabolites in serum; $25(\mathrm{OH}) \mathrm{D}$ has a relatively long half-life (15 days) compared to $1,25(\mathrm{OH})_{2} \mathrm{D}(15 \mathrm{~h})$. However, health organizations across the globe differ significantly in their definition of what level of total circulating $25(\mathrm{OH}) \mathrm{D}$ constitutes sufficiency and deficiency for a "normal" population without evidence of active bone disease (e.g., osteoporosis,

TABLE 2 | Cell types that express both CYP27B1 and VDR.

Cells co-expressing a functional CYP27B1 and VDR

\begin{tabular}{ll}
\hline Macrophage & Enterocyte \\
Dendritic cell & Decidual stromal cell \\
Parathyroid cell & Fetal trophoblast \\
Osteoblast & Prostate epithelial cell \\
Osteoclast & Vascular endothelial cell \\
Keratinocyte & Pancreatic $\beta$ cell \\
Mammary epithelial cell & Renal tubular cell
\end{tabular}

In contrast to the endocrine action based on kidney production of $1,25(\mathrm{OH})_{2} \mathrm{D}$ that travels through the general circulation to VDR-possessing target cells, a number of cell types harbor both CYP27B1 and VDR making intracrine metabolism and action possible. The red arrow indicates the macrophage, the cell type in which the intracrine metabolism of $25(\mathrm{OH}) \mathrm{D}$ to $1,25(\mathrm{OH})_{2} \mathrm{D}$ and $1,25(\mathrm{OH})_{2} \mathrm{D}$-directed gene expression has been most clearly demonstrated ex vivo. hyperparathyroidism, etc.). In North America, the Institute of Medicine has recommended the value of $\geq 20 \mathrm{ng} / \mathrm{ml} 25(\mathrm{OH}) \mathrm{D}$ (50 nmol/L) for sufficiency (45), whereas the Endocrine Society recommended for $\geq 30 \mathrm{ng} / \mathrm{ml}(75 \mathrm{nmol} / \mathrm{L})$ (46). The Vitamin D Council states that individuals should strive for levels above $40 \mathrm{ng} / \mathrm{ml} \mathrm{(100} \mathrm{nmol/L)} \mathrm{(47).} \mathrm{In} \mathrm{contrast} \mathrm{to} \mathrm{this,} \mathrm{the} \mathrm{UK} \mathrm{Science}$ Advisory Council on Nutrition defined vitamin D deficiency as serum levels of $25(\mathrm{OH}) \mathrm{D}<10 \mathrm{ng} / \mathrm{ml}(25 \mathrm{nmol} / \mathrm{L})$, but did not recommend an optimal level for human health (48). Although the $10 \mathrm{ng} / \mathrm{ml}$ level is held by some other European nations, some have recommended higher levels (49). Investigators in the vitamin D field have highlighted the limitations of the total $25(\mathrm{OH}) \mathrm{D}$ as the routine biomarker for vitamin $\mathrm{D}$ status in various commentary and review articles $(50,51)$ and discussed other potential markers and the possible need of a "vitamin D panel" $(52,53)$.

Human data indicates that the threshold for detection of a relative increase in the serum iPTH at the individual and population level occurs when the total serum 25(OH)D level falls below $\sim 30 \mathrm{ng} / \mathrm{ml}(54,55)$. Thus, PTH offers a measurable biological consequence of "low" 25(OH)D. However, PTH levels are not exclusively controled by $25(\mathrm{OH}) \mathrm{D}$ as serum concentration of ionized calcium is sensed at the parathyroid gland by the calcium-sensing receptor (CaSR). When serum calcium levels drop, CaSR signal transduction in the parathyroid yields an increase in PTH production that then enters the general circulation resulting in PTH's endocrine effects.

Another reason for the uncertainty concerning the validity of total $25(\mathrm{OH}) \mathrm{D}$ as an exclusive serum marker for vitamin $\mathrm{D}$ health is due to the complex molecular biology and biochemistry of $25(\mathrm{OH}) \mathrm{D}$-associated bioactivities. This is particularly relevant to the intracrine, paracrine or endocrine conversion of $25(\mathrm{OH}) \mathrm{D}$ to active $1,25(\mathrm{OH})_{2} \mathrm{D}$, because (i) the local concentrations vitamin $\mathrm{D}$ metabolites outside of the serum compartment cannot be easily measured in vivo and (ii) the subsequent molecular actions of $1,25(\mathrm{OH})_{2} \mathrm{D}$ in conjunction with its binding by the VDR is dependent on diverse mechanisms beyond simple variations in circulating $25(\mathrm{OH}) \mathrm{D}$. These include: (1) the transport and target tissue uptake of $25(\mathrm{OH}) \mathrm{D}$; (2) the directed intracellular transport of $25(\mathrm{OH}) \mathrm{D}$ to the inner mitochondrial to CYP27B1 for enzymatic conversion of $25(\mathrm{OH}) \mathrm{D}$ to $1,25(\mathrm{OH})_{2} \mathrm{D}$; (3) export if $1,25(\mathrm{OH})_{2} \mathrm{D}$ from the mitochondia and binding of $1,25(\mathrm{OH})_{2} \mathrm{D}$ to VDR; and (4) competing catabolism of $1,25(\mathrm{OH})_{2} \mathrm{D}$ by the enzyme CYP24A1 also located on the inner mitochondrail membrane. In this review, we will briefly discuss the molecular biology and biochemistry behind these processes, with particular emphasis on the role of free $25(\mathrm{OH}) \mathrm{D}$ as a key determinant of the downstream actions of $1,25(\mathrm{OH})_{2} \mathrm{D}$, specifically in bone and mineral health.

\section{MOLECULAR BIOLOGY AND BIOCHEMISTRY OF VITAMIN D ACTION}

$1,25(\mathrm{OH})_{2} \mathrm{D}$ is the active vitamin $\mathrm{D}$ molecule with $25(\mathrm{OH}) \mathrm{D}$ being its immediate precursor (panel A, Figure 1). It is $1,25(\mathrm{OH})_{2} \mathrm{D}$ that drives vitamin $\mathrm{D}$-regulated gene expression in target cells. Under normal conditions, the level of serum 
$1,25(\mathrm{OH})_{2} \mathrm{D}$ is tightly regulated within a narrow range (30$60 \mathrm{pg} / \mathrm{ml}$ ) at a level that is $1,000 \mathrm{X}$ less plentiful than its $25(\mathrm{OH}) \mathrm{D}$ precursor. In non-pregnant humans, $1,25(\mathrm{OH})_{2} \mathrm{D}$ in the serum comes almost exclusively from expression of CYP27B1 in the kidney. Circulating $1,25(\mathrm{OH})_{2}$ D's endocrine actions are to regulate the serum level of calcium by optimizing intestinal calcium absorption and/or calcium resorption from the skeleton (56). Not surprisingly then, when kidney failure occurs, there is (i) an accompanying decrease in renal CYP27B1 capacity, (ii) a fall in $1,25(\mathrm{OH})_{2} \mathrm{D}$ production and (iii) a reduction in the serum calcium level. In the opposite case, when a pathophysiological extra-renal source of CYP27B1 (e.g., the macrophage in granuloma-forming diseases; see right panel, Figure 1 and Table 1) becomes dysregulated and dominant, serum $1,25(\mathrm{OH})_{2} \mathrm{D}$-driven hypercalcemia and/or hypercalciuria $\left[1,25(\mathrm{OH})_{2} \mathrm{D}\right.$ intoxication] occurs overriding the calcium-lowering actions of the CaSR in the parathyroid gland and in the kidney (57). Only in these two abnormal calcemic states is the serum level of $1,25(\mathrm{OH})_{2} \mathrm{D}$ of the host informative to the clinician in evaluating a patient.

At the molecular level, $1,25(\mathrm{OH})_{2} \mathrm{D}$ binds VDR with the highest affinity among all vitamin $\mathrm{D}$ metabolites regardless of whether $1,25(\mathrm{OH})_{2} \mathrm{D}$ is coming from the serum outside the target cell (endocrine mode), from the local microenvironment outside of the serum compartment (paracrine mode), or from the inside of the cell (intracrine mode) (58). In the $1,25(\mathrm{OH})_{2} \mathrm{D}$ liganded state the VDR preferentially forms heterodimers with retinoic acid $X$ receptor (RXR). In the $1,25(\mathrm{OH})_{2} \mathrm{D}$ occupied state the VDR and its unliganded RXR partner heterodimer become transacting complexes binding to specific cis-acting vitamin D response elements (VDREs) in the genome. The heterodimer interacts with the transcriptional machinery resulting in $1,25(\mathrm{OH})_{2} \mathrm{D}$-regulated (positive or negative) gene expression and corresponding bioactivities. Due to the threedimensional "looping" nature of DNA-protein interactions, VDRE-like enhancer and repressor motifs can found at considerable distance from the transcriptional start site of a vitamin D regulated gene $(59,60)$.

Owing to a rapidly growing skeleton with a high demand for calcium and phosphate for skeletal mineralization and in the face of normal VDR and CYP27B1 activity, children suffering from low 25(OH)D levels and secondary decreases in optimal intestinal absorption in dietary calcium and phosphate can develop vitamin D deficient rickets (61). This is commonly observed in subpopulations of impoverished, dark-skinned children (i) who require up to 10 times more cutaneous sunlight exposure that lightly pigmented children to make the same amount of vitamin D in their skin and (ii) in whom consumption of natural vitamin D-rich foods (e.g., fish) and vitamin $\mathrm{D}$ supplemented foods is compromised. In nations of lower income, children usually consume a diet rich in grains; grains are a rich source of phytates known to chelate ingested calcium further decreasing intestinal calcium absorption. Vitamin D deficiency rickets can also be hastened in children subjected to religious/cultural practices that (e.g., occlusive garb) that effectively eliminate skin exposure to sunlight. In vitamin $\mathrm{D}$ deficient rickets the serum calcium and phosphate is low and PTH and $1,25(\mathrm{OH})_{2} \mathrm{D}$ usually elevated for the subject's age (62). A low 25(OH)D level (usually $<10 \mathrm{ng} / \mathrm{ml}$ ) is the distinguishing marker for vitamin $\mathrm{D}$ deficient rickets, distinguishing it from Human Vitamin D Resistant Rickets (HVDRR; high 1,25(OH) 2 D) and Pseudo Vitamin D Deficient Rickets (PDDR; low 1,25(OH) 2 D) (63). Appropriate dietary supplementation with calcium and vitamin $\mathrm{D}$ to normalize the serum 25(OH)D level (e.g., >30 ng/ml) alleviates nutritional rickets $(61,64)$.

Prevention of nutritional rickets in children and osteomalacia in adults is the primary concern behind the recommendations on vitamin $\mathrm{D}$ intake and serum $25(\mathrm{OH}) \mathrm{D}$ level attainment. Various medical organizations have evaluated the existing body of research data to support their positions and are exhaustively reported elsewhere $(45,48)$. However, two key studies are emblematic of the basis for the determinations. In one line of evidence, PTH is used as a biomarker of bone health. In some studies, an inverse association between PTH (declining) and $25(\mathrm{OH}) \mathrm{D}$ (increasing) has been observed $(55,65,66)$. In one study involving 1,536 post-menopausal women (55) an inflection point where the decline in serum PTH levels off was identified at a $25(\mathrm{OH}) \mathrm{D}$ level of $30 \mathrm{ng} / \mathrm{ml}$, leading some authorities in the vitamin $\mathrm{D}$ field to call for this to demarcate the cutoff for vitamin D sufficiency (46). Another often quoted study involved post-mortem $(N=675)$ determination of 25(OH)D levels and comparisons to histomorphometric analysis of transiliac crest biopsies (67). From this dataset, the IOM (45) concluded that at a serum 25(OH)D level of $20 \mathrm{ng} / \mathrm{ml}$ and above, $99 \%$ of the normal population (e.g., without a known bone disease) should have no pathological accumulation of osteoid (unmineralized portion of bone indicative of rickets in children and osteomalacia in adults). Interestingly, the original authors (67) using different criteria to analyze the same data concluded that $30 \mathrm{ng} / \mathrm{ml} 25(\mathrm{OH}) \mathrm{D}$ as the recommended level for optimal skeletal health.

\section{TOTAL 25(OH)D OR FREE 25(OH)D?}

The measured total $25(\mathrm{OH}) \mathrm{D}$ concentration in serum is present at nearly 1,000-fold higher levels compared to $1,25(\mathrm{OH})_{2} \mathrm{D}$ in serum and easily and accurately measured from a small amount of sample $(25-50 \mu \mathrm{l})(68)$. As such, total $25(\mathrm{OH}) \mathrm{D}$ has become the de facto biomarker of the state of vitamin $\mathrm{D}$ deficiency or sufficiency of the host. However, the majority (>99\%) of serum $25(\mathrm{OH}) \mathrm{D}$ is bound (Figure 1, left box) to carrier proteins ( $\sim 85 \%$ to vitamin D binding protein [DBP]; $\sim 15 \%$ to albumin). The affinity of DBP for $25(\mathrm{OH}) \mathrm{D}$ is $\sim 1,000$-fold greater than that of albumin for $25(\mathrm{OH}) \mathrm{D}$ (11). Cells that express the cell surface receptor proteins megalin and cubulin can internalize the DBP-bound-25(OH)D complex into an endolysosome with ultimate release of $25(\mathrm{OH}) \mathrm{D}$ from $\mathrm{DBP}$ into the cell interior for further metabolism and/or catabolism of $25(\mathrm{OH}) \mathrm{D}$. This mechanism of endocytosis, intracellular release of $25(\mathrm{OH}) \mathrm{D}$ from acid-hydrolyzed DBP has been most clearly demonstrated at the luminal membrane of the tubular epithelial cells in the kidney 
(15). Here internalized $25(\mathrm{OH}) \mathrm{D}$ is the substrate used by the CYP27B1 to form $1,25(\mathrm{OH})_{2} \mathrm{D}$ for endocrine distribution. In cells not expressing megalin, 25(OH)D entry into its target cell is proposed to be accomplished by diffusion of the unbound, free $25(\mathrm{OH}) \mathrm{D}$ across the lipid bilayer of the plasma membrane to the cell interior (15). Thus, the biologically relevant substrate for some cells is DBP-bound $25(\mathrm{OH}) \mathrm{D}$ (essentially equal to total $25(\mathrm{OH}) \mathrm{D})$ and for others it is the free $25(\mathrm{OH}) \mathrm{D}$ or a related metric of bioavailable $25(\mathrm{OH}) \mathrm{D}$ (sum of free $25(\mathrm{OH}) \mathrm{D}$ and albumin-bound-25(OH)D).

Though the serum protein carriers of vitamin $\mathrm{D}$ metabolites are well-characterized, it is now clear that vitamin D metabolites also reside in non-serum locales such as body fat and inside cells, suggesting that specific vitamin $\mathrm{D}$ binding proteins other than DBP and albumin may also play a role in vitamin D biology. Notably intracellular vitamin D binding proteins (IDBPs) were identified as a result of investigations into apparent vitamin D resistance in New World Primates [NWP; reviewed in Adams et al. $(69,70)]$. The high serum levels of steroid hormones in general and vitamin $\mathrm{D}$ in particular, relative to Old World Primates (OWP), was shown to be associated with a form of target tissue insensitivity to $1,25(\mathrm{OH})_{2} \mathrm{D}$ (71). The first indications of a functional role for IDBPs was the observed diminished ability of NWP cells to effectively upregulate VDRtarget genes, like the CYP24A1, despite having comparable amounts of $\operatorname{VDR}(72,73)$ and $\operatorname{VDR}$ functionality (74). Using cell extracts from NWP and OWP in VDR-1,25(OH $)_{2} \mathrm{D}$ radiolabel binding assays, a protein in NWP cell extracts was observed to prevent VDR-1,25(OH $)_{2} \mathrm{D}$ binding when mixed with OWP extracts. This inhibition of binding was abolished after trypsin digestion or heat denaturation (75). Upon further characterization, IDBP was found to (i) bind $25(\mathrm{OH}) \mathrm{D}$ as well as other steroid hormones (76) and (ii) be part of the heat shock protein 70 family $(77,78)$. With cDNA constructs for IDBP obtained, transient and stable overexpression in vitro in tissue culture studies revealed that IDBP could increase $1,25(\mathrm{OH})_{2} \mathrm{D}$ synthesis, possibly by chaperoned delivery of $25(\mathrm{OH}) \mathrm{D}$ to the CYP27B1 (79). The ATPase domain of IDBP was essential to this function $(80,81)$, with the BCL2-associated athanogene 1 (BAG1) serving as an IDBP co-chaperone (82).

Measurement of the free, unbound form of $25(\mathrm{OH}) \mathrm{D}$ in serum is challenging, because its levels are low $(4-8 \mathrm{pg} / \mathrm{ml}$ range) and has historically required radioactive tracers of $25(\mathrm{OH}) \mathrm{D}$ with equilibrium or centrifugal dialysis methods that are cumbersome and impractical for use in clinical laboratory testing services $(10,11)$. Free and bioavailable $25(\mathrm{OH}) \mathrm{D}$ levels in the serum can be mathematically calculated using equations that incorporate the binding affinity of DBP for $25(\mathrm{OH}) \mathrm{D}$ and the concentration of DBP in the serum $(11,83)$. This approach of calculating the free, biologically active fraction of $25(\mathrm{OH}) \mathrm{D}$ has also been taken with testosterone (84) and thyroid hormone (85). Unfortunately, for free $25(\mathrm{OH}) \mathrm{D}$, it was discovered that one commonly used DBP ELISA kit used to calculate for free $25(\mathrm{OH}) \mathrm{D}$ had differential sensitivities to the common phenotypic variants of DBP (discussed later in this review) that resulted in inaccurate measurement of DBP concentrations in some samples
TABLE 3 | Hormone binding proteins found in human serum.

\begin{tabular}{|c|c|c|c|}
\hline \multirow{2}{*}{$\begin{array}{l}\text { Binding protein } \\
\text { DBP } \\
4.5-5.5 \mu \mathrm{M}^{a}\end{array}$} & \multicolumn{2}{|c|}{ Metabolites } & \multirow{2}{*}{$\begin{array}{c}\text { Percent fre } \\
0.02\end{array}$} \\
\hline & $\begin{array}{c}\text { Total } 25(\mathrm{OH}) \mathrm{D} \\
25-75 \mathrm{nM}^{\mathrm{a}}\end{array}$ & $\begin{array}{c}\text { Free } 25(\mathrm{OH}) \mathrm{D} \\
5-20 \mathrm{pM}^{\mathrm{a}}\end{array}$ & \\
\hline & $\begin{array}{c}\text { Total } 1,25(\mathrm{OH})_{2} \mathrm{D} \\
50-198 \mathrm{pM}^{\mathrm{b}}\end{array}$ & $\begin{array}{c}\text { Free } 1,25(\mathrm{OH})_{2} \mathrm{D} \\
325-525 \mathrm{fM}^{\mathrm{C}}\end{array}$ & 0.5 \\
\hline \multirow[t]{2}{*}{$\begin{array}{l}\text { TBG } \\
\text { 241-722 nM }\end{array}$} & $\begin{array}{c}\text { Total T4 } \\
58-154 \mathrm{nM}^{\mathrm{b}}\end{array}$ & $\begin{array}{c}\text { Free T4 } \\
11-23 \mathrm{pM}^{\mathrm{b}}\end{array}$ & 0.02 \\
\hline & $\begin{array}{c}\text { Total T3 } \\
1.1-2.8 \mathrm{nM}^{\mathrm{b}}\end{array}$ & $\begin{array}{c}\text { Free T3 } \\
3.0-6.8 \mathrm{pM}^{\mathrm{b}}\end{array}$ & 0.3 \\
\hline \multirow{2}{*}{$\begin{array}{l}\text { SHBG } \\
16.5-55.9 \mathrm{nM}^{\mathrm{b}} \\
\text { (male) }\end{array}$} & $\begin{array}{c}\text { Male total T } \\
9.2-31.8 \mathrm{nM}^{\mathrm{b}}\end{array}$ & $\begin{array}{l}\text { Male free } T \\
\text { 30-87 } \text { pM }^{\mathrm{b}}\end{array}$ & 0.3 \\
\hline & $\begin{array}{l}\text { Male total E2 } \\
28-156 \mathrm{pM}^{\mathrm{b}}\end{array}$ & $\begin{array}{c}\text { Male free E2 } \\
<1.7 \mathrm{pM}^{\mathrm{d}}\end{array}$ & 1 \\
\hline \multirow{2}{*}{$\begin{array}{l}\text { SHBG } \\
24.6-122.0 \mathrm{nM}^{\mathrm{b}} \\
\text { (female) }\end{array}$} & $\begin{array}{c}\text { Female total T } \\
0.3-1.7 \mathrm{nM}^{\mathrm{b}}\end{array}$ & $\begin{array}{c}\text { Female free } T \\
<15 \mathrm{pM}^{\mathrm{b}}\end{array}$ & 0.9 \\
\hline & $\begin{array}{c}\text { Female total E2 } \\
46-609 \mathrm{pM}^{\mathrm{b}}\end{array}$ & $\begin{array}{l}\text { Female free E2 } \\
1.6-18.5 \mathrm{pM}^{\mathrm{d}}\end{array}$ & 3 \\
\hline
\end{tabular}

${ }^{a}$ Nielson et al. (88).

${ }^{b}$ https://www.labcorp.com/test-menu/search.

${ }^{c}$ Bikle et al. (89).

${ }^{d}$ https://www.questdiagnostics.com/testcenter/TestCenterHome.action.

Vitamin $D$ binding protein (DBP), thyroxine binding globulin (TBG), and sex hormone binding globulin (SHBG) are tabulated with their serum concentration levels. The respective metabolite concentrations total, free and percent free are also presented. Albumin can bind all the hormones listed and transthyretin can bind T4 albeit at lower affinity compared to their primary carrier proteins. The bioavailable concept has been applied to these hormones and comprise the sum of albumin-bound-hormone and free hormone.

leading to inaccurate calculated free $25(\mathrm{OH}) \mathrm{D}$ levels in those serum samples.

Direct measurement of the various free hormones of clinical importance have been developed $(86,87)$. However, this aspect of clinical chemistry remains challenging due to (i) the low concentration of these metabolites in the serum (Table 3 ) and (ii) variability of serum composition (e.g., lipids and other potentially interfering molecules) between patients that can introduce error into the measured value. Recently, an ELISA based method for detection of free 25(OH)D has been developed (90) and has been utilized in a number of clinical studies that we will summarize in the clinical studies portion of this review. Most recently, a highthroughput method to measure bioavailable $25(\mathrm{OH}) \mathrm{D}$ has been developed (91). However, procedures to ensure accuracy and precision across a wide range of sample conditions both for both of these assays have not been yet developed; as a consequence, these assays are deemed for research use only.

\section{MOLECULAR BIOLOGY AND BIOCHEMISTRY OF DBP}

The vitamin $\mathrm{D}$ binding protein (DBP) is a multi-functional protein also known as Group Specific Component (GC) [reviewed in Chun (92) and Delanghe et al. (93)]. DBP is a member of the albumin superfamily of proteins. DBP is a moderately abundant protein $(\sim 5 \mu \mathrm{M}$ in humans) in serum of 
TABLE 4 | Molecular biology of most common DBP polymorphisms.

\begin{tabular}{llll}
\hline SNP name & GC name & Codon variant & Amino acid variant \\
\hline rs4588 & GC1 & ACG & Thr-436 \\
& GC2 & AAG & Lys-436 \\
rs7041 & GC1F & GAT & Asp-432 \\
& GC1S & GAG & Glu-432
\end{tabular}

Two single nucleotide polymorphisms (SNP) account for three of the major forms of DBP (originally known as GC-globulin). Table also includes the specific codon and amino acid variation that define these variants.

vertebrates. In humans the GC/DBP 13 exon gene is located at $4 q 13.3$. Its gene product, DBP, is highly expressed in the liver and exported into the circulatory system. DBP contains 474 amino acids of which the $16 \mathrm{~N}$-terminal amino acids function as a signal peptide. DBP can be glycosylated (94) to varying degrees depending on genotype. The glycosylation pattern has been suggested to be structural basis for the macrophage activating factor activity of DBP $(95,96)$.

DBP's most well-characterized role is that of a carrier protein for vitamin $\mathrm{D}$ metabolites. Its rank order avidity for the vitamin $\mathrm{D}$ and it metabolites are $(10,11,89,97)$ as follows: $24,25(\mathrm{OH})_{2} \mathrm{D}>25(\mathrm{OH}) \mathrm{D}>1,25(\mathrm{OH})_{2} \mathrm{D}>$ vitamin $\mathrm{D}$. DBP binds vitamin $\mathrm{D} 3$ and its metabolites with greater affinity than vitamin D2 and it metabolites (97). DBP can also bind actin (98). This biological action is suggested to be that of scavenging of exposed actin, preventing overzealous extracellular polymerization after tissue injury (99). DBP can also bind circulating fatty acids (100) and C5a des Arg, the latter of which enhances complement activation (101).

DBP migrates at $\sim 52-59 \mathrm{kDa}$ in electrophoretic gels (102). It was variations in DBP mobility in isoelectric focusing (IEF) gels that garnered initial research attention prior to its function being determined. One banding pattern was termed GC-1F (faster), another GC-1S (slower), and still another GC2 (103). GC2 migrated less rapidly toward the anode compared to either GC1 forms. The different forms, due to single amino acid differences (Table 4), were (i) used to determine allelic frequency for samples worldwide (104) and (ii) found to associate with the racial background of the source human serum. In the Kamboh study, black subjects were more likely to have the GC1F forms (67-79\% of alleles in USA blacks) while white subjects more frequently yielded the GC1S pattern (49-57\% of alleles in USA whites). The GC2 allele was observed were more frequently seen in white subject samples (21-31\% in USA whites) compared to blacks ( $8-13 \%$ in USA blacks). These three classic forms (GC1F, GC1S, and GC2) account for the vast majority of the variation DBP across human populations. Since these early studies, many other SNPs (105) have been found in GC of which a small percentage encodes a missense mutation that changes the amino acid code.

\section{Affinity Differences and DBP Genotype}

The biological significance of DBP's different allelic forms is unclear. Conceptually, if the different genotypic forms of DBP had different affinities for vitamin $\mathrm{D}$ metabolites, then the levels of those metabolites could be influenced by the genotype. However, in terms of experimentally measured differences in affinity for vitamin $\mathrm{D}$ metabolites, one study reported large differences (106) but three others did not (107-109). Media supplemented with serum that contained different alleles of DBP had differing impacts on assessed immunological readouts consistent with affinity differences in three in vitro studies (110-112). The mechanism for the observed differences were not investigated in those studies; thus, non-affinity dependent mechanisms cannot be ruled out. Using an ELISA based assay to detect free $25(\mathrm{OH}) \mathrm{D}$, some small differences in percent free were detected between the genotypes (113). However, these differences were smaller in magnitude than the differences anticipated if the report of large affinity difference among genotype was accurate.

\section{DBP Serum Concentration and DBP Genotype}

The other mechanism by which DBP genotype could impact free $25(\mathrm{OH}) \mathrm{D}$ levels is through differentials in the genotypedependent DBP concentration. It is on this basis that Powe et al. (114) proposed how black Americans, with lower total serum 25(OH)D levels and substantially lower DBP levels compared to white Americans, could ultimately have similar free 25(OH)D levels. However, it was eventually determined that the monoclonal antibody-based ELISA used in their study was less sensitive to the GC1F DBP, the form most frequently found in blacks $(88,115)$. This resulted in an underestimation of serum DBP levels in black subjects and a consequent overestimation of the calculated free and bioavailable serum 25(OH)D levels in their serum. Nonetheless, there is evidence of some genotypic effect on DBP concentrations. One early study (116) of Danish women found DBP concentration ranked according to the presence of GC1 alleles (GC1-GC1 > GC1-GC2 > GC2-GC2). Consistent with those findings was a study in a population male subjects with modest racial diversity where GC2/GC2 subjects exhibited the lowest serum DBP concentration (88).

In another recent study utilizing serum samples from both women and men with modest racial diversity, the presence of the GC2 allele in one of three allelic combinations resulted in lower DBP levels compared to the three allelic combinations without GC2 (113). Currently, it is thought that DBP's role in determining free $25(\mathrm{OH}) \mathrm{D}$ levels is largely through its concentration [i.e., for a fixed total $25(\mathrm{OH}) \mathrm{D}$, more DBP yields less free $25(\mathrm{OH}) \mathrm{D}]$ and perhaps to a small degree by genotype. As such, in most cases total $25(\mathrm{OH}) \mathrm{D}$ and free $25(\mathrm{OH}) \mathrm{D}$ are highly correlated. However, there are some conditions where DBP levels diverge from typical levels. For instance, patients with liver disease have lower levels of DBP while pregnant women have higher DBP levels $(89,117)$ resulting in higher free $25(\mathrm{OH}) \mathrm{D}$ levels in those with lower DBP concentrations. In the more extreme case of patients before [lower DBP, lower 25(OH)D] and after [higher DBP, higher 25(OH)D] liver transplants, the percentage of free $25(\mathrm{OH}) \mathrm{D}$ relative to total $25(\mathrm{OH}) \mathrm{D}$ is higher before transplantation. Recently, a case report described a subject with 
a homozygous deletion of DBP (118). Compared to unaffected and heterozygous siblings, the affected patient had no DBP and very low serum levels of $25(\mathrm{OH}) \mathrm{D}$ and $1,25(\mathrm{OH})_{2} \mathrm{D}$. Despite the extremely low serum levels of vitamin D metabolites, the subject had normal calcium balance with only relatively small alterations in bone health and mineral metabolism. This case report is the strongest evidence to date that the total serum $25(\mathrm{OH}) \mathrm{D}$ and $1,25(\mathrm{OH})_{2} \mathrm{D}$ level can be disconnected from "normal" vitamin D status. One explanation is that albumin, or some other chaperone in the serum, assumes the role of delivering $25(\mathrm{OH}) \mathrm{D}$ and maintaining viable levels of free $25(\mathrm{OH}) \mathrm{D}$ and $1,25(\mathrm{OH})_{2} \mathrm{D}$, as was measured in this subject, to target tissues for further metabolism and action.

\section{ANIMAL STUDIES OF FREE 25(OH)D AND BONE}

Dbp heterozygous and homozygous knockouts in mice do not have any obvious bone phenotype relative to wild type (119). However, with the loss of a single copy of Dbp the levels of circulating total serum $25(\mathrm{OH}) \mathrm{D}$ and $1,25(\mathrm{OH})_{2} \mathrm{D}$ are diminished and when both copies were absent, the levels of serum $25(\mathrm{OH}) \mathrm{D}$ and $1,25(\mathrm{OH})_{2} \mathrm{D}$ were extremely low, phenocopying the $D B P^{-/-}$subject just described above. Interestingly, neither $\mathrm{DBP}^{+/-}$or $\mathrm{DBP}^{-/-}$mice exhibited any skeletal abnormalities or problems with calcium and phosphate balance (119). These findings support the hypothesis that free hormone levels alone are adequate for sustaining skeletal health. Consistent with this was another study with $D b p$ homozygous knockouts where the levels of $1,25(\mathrm{OH})_{2} \mathrm{D}$ was measured in the intestinal tissues (120). Even though the double knockout animals had very low total serum $1,25(\mathrm{OH})_{2} \mathrm{D}$ levels compared to wild type, the levels of $1,25(\mathrm{OH})_{2} \mathrm{D}$ measured in the intestinal tissues were very similar. These findings suggest that trace amounts of free metabolites and/or enhanced local conversion of $25(\mathrm{OH}) \mathrm{D}$ to $1,25(\mathrm{OH})_{2} \mathrm{D}$ are sufficient as long as sufficient amounts substrate $25(\mathrm{OH}) \mathrm{D}$ are available to the host. The fact that mice with no DBP are still viable suggests that albumin, though having a much lower affinity for vitamin D metabolites, could serve as the carrier protein in place of DBP. When Dbp null mice were raised on vitamin D3-free diets, they developed secondary hyperparathyroidism and bone mineralization defects much more rapidly than paired wild-type mice (119). This result indicated that DBP's function is to maintain a stable reservoir of circulating extracellular vitamin $\mathrm{D}$ metabolites. Owing to its higher affinity for vitamin $\mathrm{D}$ metabolites, DBP is more effective in this role than albumin, despite both DBP and albumin being filtered into the urine and reclaimed by megalin.

Another test of the biological impact of free $25(\mathrm{OH}) \mathrm{D}$ in mice (121) was based on the difference in affinity of DBP for D2 or ergocalciferol (vitamin D found in fungi) vs. D3 or cholecalciferol (vitamin $\mathrm{D}$ found in animals) forms of vitamin $\mathrm{D}$ metabolites. Mice raised on diets containing exclusively D2 or D3 would result in the mice having only $25(\mathrm{OH}) \mathrm{D} 2$ and $25(\mathrm{OH}) \mathrm{D} 3$ circulating in their serum. Since DBP affinity for D2 forms is lower relative to D3 forms, the free 25(OH)D2 levels were expected to be higher in animals raised on D2 diets. In this study, mice were placed on D2 or D3 diets $(1,000 \mathrm{IU} / \mathrm{kg})$ beginning at week 3 and tested at week 8 and week 16 for 25(OH)D3 and 25(OH)D2 serum levels and bone phenotype by histomorphometry. These mice had similar total $25(\mathrm{OH}) \mathrm{D}$ levels at week $8(26.6 \pm 1.9 \mathrm{ng} / \mathrm{ml}$ $25(\mathrm{OH}) \mathrm{D} 2$ vs. $28.3 \pm 2.0 \mathrm{ng} / \mathrm{ml} 25(\mathrm{OH}) \mathrm{D} 3)$ and at week $16(33.3$ \pm 4.4 vs. $31.7 \pm 2.1 \mathrm{ng} / \mathrm{ml})$. However, as anticipated, they differed in their free $25(\mathrm{OH}) \mathrm{D}$ levels with free $25(\mathrm{OH}) \mathrm{D} 2$ greater than free $25(\mathrm{OH}) \mathrm{D} 3$ at week $8(16.8 \pm 0.65$ vs. $8.4 \pm 0.63 \mathrm{pg} / \mathrm{ml}$, $P<0.001)$ and at week $16(17.4 \pm 0.43$ vs. $8.4 \pm 0.44, P<$ 0.001 ). Histomorphometric analysis of their bones detected that at week 8, the D2 fed mice had significantly higher osteoclast surface/bone surface, eroded surface/bone surface, and mineral apposition rate (high bone turnover) compared with mice raised on the D3 diets. Additionally, osteoblast surface/bone surface, an index of bone formation, was higher in week 8 D2 in females only. The reason underpinning this sexual dimorphism in bone formation rates remains unknown. The bone phenotype at week 16 revealed significantly higher bone volume/total volume and trabecular number in the D2 mice relative to the D3 mice. Taken together, despite similar total serum 25(OH)D levels, bone phenotype differences were observed in association with different free $25(\mathrm{OH}) \mathrm{D}$ levels (higher in $\mathrm{D} 2$ mice) suggesting the relevance of free $25(\mathrm{OH}) \mathrm{D}$ to bone health.

To the best of our knowledge, there have been no studies on the effects of free $25(\mathrm{OH}) \mathrm{D}$ and the bone health of animals besides the studies in mice summarized above. However, the existence of nocturnal bats that roost in dark locations (122) could be informative. These bats have very low total serum $25(\mathrm{OH}) \mathrm{D}(<5 \mathrm{ng} / \mathrm{ml})$ as their normal state suggesting that "deficient" (by human standards) total $25(\mathrm{OH}) \mathrm{D}$ levels presumably still yields adequate free $25(\mathrm{OH}) \mathrm{D}$ levels to sustain normal bone and mineral homeostasis for this species. Interestingly, these bats are fully capable of attaining higher $25(\mathrm{OH}) \mathrm{D}$ levels when housed in conditions that expose them to sunlight. Perhaps these animals have lower DBP concentrations or metabolite affinities for DBP to compensate for their naturally low total serum $25(\mathrm{OH}) \mathrm{D}$ levels. A test of these animal's serum with the free $25(\mathrm{OH}) \mathrm{D}$ assay could be informative. Other possible adaptations that permit compensation to the very low circulating levels of $25(\mathrm{OH}) \mathrm{D}$ include: (1) a highly efficient CYP27B1; (2) hyper-sensitive VDR to ligand; (3) heightened transactivation potential of VDR-interacting coactivators; and/or (4) diminished functional activity of the CYP24A1 catabolic machinery. There is one study comparing DBP affinity for 25-hydroxyvitamin D among several animals; these investigators found the DBP from rat and cattle exhibited higher affinity to $25(\mathrm{OH}) \mathrm{D}$ compared to horse and rhesus monkey with humans having the lowest affinity of species tested (123). What the levels of free $25(\mathrm{OH}) \mathrm{D}$ are and its importance to these species have not yet been examined.

\section{HUMAN STUDIES OF FREE 25(OH)D}

Revitalized interest on the impact of vitamin D on human health beyond bone was spurred by studies that investigated 
vitamin D's regulatory role in the adaptive and innate immune system $(26,29,124)$. Three in vitro studies have demonstrated that decreasing free $25(\mathrm{OH}) \mathrm{D}$ by increasing DBP in the culture media diminished immune functions of adherent monocytes (110), dendritic cells (111), and T-lymphocytes (112). Because of these findings in vitro, the parameter of free $25(\mathrm{OH}) \mathrm{D}$ began to receive greater interest in clinical research. In non-bone health association studies, the results have been mixed. In some studies free serum $25(\mathrm{OH}) \mathrm{D}$ levels were inversely associated with coronary artery disease (125), pediatric inflammatory bowel disease (126) and ulcerative colitis (127), insulin sensitivity (128), reduction in lipid markers in statin patients (129), and acromegaly (130). However, in some other studies free $25(\mathrm{OH}) \mathrm{D}$ was inferior in asthma (131) and no better than total $25(\mathrm{OH}) \mathrm{D}$ for colorectal cancer in AfricanAmericans (132).

Concerning bone and mineral health, a 2011 report (133) was the first to utilize free $25(\mathrm{OH}) \mathrm{D}$ and the related concept bioavailable $25(\mathrm{OH}) \mathrm{D}$ (sum of free $25(\mathrm{OH}) \mathrm{D}$ and albuminbound $25(\mathrm{OH}) \mathrm{D})$ for analytical purposes. They found that these two metrics of serum vitamin D status were more closely and directly associated with BMD in the individual than total serum $25(\mathrm{OH}) \mathrm{D}$. This group then followed up with another report (134) that showed that compared to measures of total $25(\mathrm{OH}) \mathrm{D}$ bioavailable $25(\mathrm{OH}) \mathrm{D}$ had a significant direct association with serum calcium (corrected for the serum albumin level) and a significant inverse association with PTH. These investigators suggested that this could address the long-standing paradox of how black Americans with lower total serum 25(OH)D levels have higher BMD and similar PTH levels compared to white Americans. In additional work, they measured DBP serum concentrations in black Americans and found them to be lower than those in white Americans. They concluded that the resultant higher bioavailable $25(\mathrm{OH}) \mathrm{D}$ may account for the nominal differences in BMD and serum PTH (114) despite what appeared to be sub-optimal total serum $25(\mathrm{OH}) \mathrm{D}$ levels; unfortunately, a high-throughput assay to directly measure free $25(\mathrm{OH}) \mathrm{D}$ was not available at that time. Thus, in these reports, measured DBP, albumin and total $25(\mathrm{OH}) \mathrm{D}$ values were input into mathematical equations $(11,84)$ to calculate values for free $25(\mathrm{OH}) \mathrm{D}$ and bioavailable $25(\mathrm{OH}) \mathrm{D}$. Disappointingly, one of the popular ELISA kits for DBP quantitation at the time relied upon a monoclonal antibody that turned out to possess reduced sensitivity to the DBP polymorphism (GC1F) most frequently found in black Americans $(88,115)$. Because of this characteristic of the ELISA, the DBP concentration was under-reported for these subjects leading to an overestimation of the calculated free and bioavailable $25(\mathrm{OH}) \mathrm{D}$. The manufacturer of this monoclonal ELISA has re-designed their ELISA and released a new version in January 2017 addressing this problem (135). Even with these complications, these early studies sparked interest in examining bone and mineral health by markers of vitamin $\mathrm{D}$ status other than the traditional total serum 25(OH)D.

Investigators have continued to use calculated free and bioavailable $25(\mathrm{OH}) \mathrm{D}$ in serum in association studies. In light of the difficulties with the monoclonal antibody-based ELISA for DBP, immunological methods based on polyclonal antibodies (less influenced by DBP polymorphisms) and techniques independent of antibodies entirely (mass spectrometry) can be employed to measure DBP for calculation of bioavailable $25(\mathrm{OH}) \mathrm{D}$ in serum $(88,115)$. Additionally, an ELISA method has been developed that measures free $25(\mathrm{OH}) \mathrm{D}$ directly (90) such that some investigators use this assay exclusively in their studies though many also include data from calculated free and/or bioavailable $25(\mathrm{OH}) \mathrm{D}$.

\section{HUMAN CLINICAL STUDIES OF FREE 25(OH)D AND BONE}

This section surveys the recent literature examining whether free (directly measured or calculated using the polyclonal DBP assay) vs. total $25(\mathrm{OH}) \mathrm{D}$ is more consistently associated with various measures of bone health, including intestinal calcium absorption, parathyroid hormone secretion, and bone mineral density.

\section{Intestinal Calcium Absorption}

To our knowledge, there has only been one study to date examining the relation between free and total $25(\mathrm{OH}) \mathrm{D}$ with intestinal calcium absorption. Aloia et al. randomized 71 adults to receive either placebo, $800,2,000$, or $4,000 \mathrm{IU} /$ days of vitamin D3 over 8 weeks. At both baseline and follow-up, neither free nor total $25(\mathrm{OH}) \mathrm{D}$ nor $1,25(\mathrm{OH})_{2} \mathrm{D}$ in the serum was associated with intestinal calcium absorption efficiency (136). This supports the concept that VDR-directed increases in intestinal calcium absorption are controlled locally, outside of the serum compartment.

\section{Parathyroid Hormone}

Multiple investigators have assessed whether free vs. total $25(\mathrm{OH}) \mathrm{D}$ is more strongly correlated with the serum PTH level, with results being inconsistent. For example, in an analysis of 155 subjects that included 24 cirrhotics and 20 pregnant women, Schwartz et al. reported that both free and total serum $25(\mathrm{OH}) \mathrm{D}$ were similarly, inversely correlated with the serum PTH (117). Similar findings have been reported in: (1) healthy pre- (137) and postmenopausal women (136); (2) individuals with obesity (138); (3) patients cirrhosis of the liver (139); (4) children (2-18 $\mathrm{y} / \mathrm{o})$ in Spain (140); (5) blacks and whites in a supplementation study (placebo, 2,000, 4,000 IU/days for 16 weeks) (141); (6) a RCT of prediabetics (142); and (7) pregnant white women in Germany (143). While the above studies reported similar correlations between serum free and total 25(OH)D with serum $\mathrm{PTH}$, others have favored free $25(\mathrm{OH}) \mathrm{D}$. For example, Schwartz et al. conducted a 16-weeks trial in which 81 older women and men received vitamin D3 at doses of $800,2,000$, or 5,000 IU/days or 50,000 IU/weeks. At the end of the study, free, but not total serum $25(\mathrm{OH}) \mathrm{D}$ was inversely associated with the serum PTH; however, free $25(\mathrm{OH}) \mathrm{D}$ explained only a small amount of the variability in PTH $\left[R^{2}=0.08\right.$; (144)]. In two, smaller trials - one in which 38 participants received 500,000 IU of vitamin D2 or D3 over 10 weeks (145) and another in which 35 participants received 2,400 IU/day of vitamin D3 or 20 $\mathrm{mcg} /$ day of 25-hydroxyvitamin D3 (146)-Shieh et al. reported 
that longitudinal increase in free $25(\mathrm{OH}) \mathrm{D}$ was significantly associated with concurrent decrease in serum PTH during the first 8-10 weeks of supplementation (when 25(OH)D levels change most rapidly), whereas increase in total $25(\mathrm{OH}) \mathrm{D}$ was not. In adults with primary hyperparathyroidism, Wang et al., similarly found that the free serum $25(\mathrm{OH}) \mathrm{D}$ was inversely correlated with circulating PTH levels, but total 25(OH)D was not (147). Further complicating the picture are studies favoring total $25(\mathrm{OH}) \mathrm{D}$ over free $25(\mathrm{OH}) \mathrm{D}$. In a cohort of Hungarian adults assessed at the end of winter total, but not free $25(\mathrm{OH}) \mathrm{D}$, was inversely correlated with PTH (148). In a study of UK whites and south Asians, total, but not free 25(OH)D, was inversely correlated with PTH (149). In a study of pregnant adolescents (13-18 y/o), the inverse association of PTH with free $25(\mathrm{OH}) \mathrm{D}$ was weaker than that observed total $25(\mathrm{OH}) \mathrm{D}(150)$.

\section{Bone Mineral Density}

While a change in the serum PTH level is the outcome that has been most frequently tested in relation to free vs. total $25(\mathrm{OH}) \mathrm{D}$, some cross-sectional studies have examined bone mineral density (BMD) as well. As was the case with changes in the serum $\mathrm{PTH}$, results with BMD have been inconsistent. For example, Jemielita et al. reported that in 304 adults, neither total nor free serum $25(\mathrm{OH}) \mathrm{D}$ at a single point in time was associated with BMD assessed by DXA, or peripheral quantitative CT (151). In contrast, in a cross-sectional analysis comparing the correlations between free vs. total serum $25(\mathrm{OH}) \mathrm{D}$ with $\mathrm{BMD}$ and composite indices of femoral neck strength, Alwan reported that higher free $25(\mathrm{OH}) \mathrm{D}$ levels were correlated with greater BMD (lumbar spine, femoral neck, total hip), and femoral neck strength $(r=0.24-$ $0.34, p<0.05)$, but total 25(OH)D was not (152). On the flip side, Michaelsson et al. reported that in women from Sweden (mean age 68 years) higher total, but not free, serum 25(OH)D was associated with greater BMD (153).

\section{CHALLENGES AND PROSPECTS}

Undoubtedly, further clinical studies should be conducted using bone/mineral outcomes as well as non-skeletal health readouts to assess the utility of free 25(OH)D. As described in the above section pertaining to bone and mineral health, human studies comparing whether free vs. total serum $25(\mathrm{OH}) \mathrm{D}$ is more frequently associated with intestinal calcium absorption, parathyroid hormone secretion, or bone mineral density have yielded inconsistent results ranging from no difference, to those

\section{REFERENCES}

1. Rosen CJ, Abrams SA, Aloia JF, Brannon PM, Clinton SK, DurazoArvizu RA, et al. IOM committee members respond to Endocrine Society vitamin D guideline. J Clin Endocrinol Metab. (2012) 97:1146-52. doi: $10.1210 /$ jc.2011-2218

2. Rosen CJ, Adams JS, Bikle DD, Black DM, Demay MB, Manson JE, et al. The nonskeletal effects of vitamin D: an Endocrine Society scientific statement. Endocr Rev. (2012) 33:456-92. doi: 10.1210/er.20 $12-1000$ favoring either free, or total $25(\mathrm{OH}) \mathrm{D}$. We propose that there are two major challenges that contribute to these inconsistencies. First, is the lack of a specific "readout" of vitamin D bioactivity. While circulating PTH levels are influenced by vitamin D status (154-156), it is also regulated by the calcium sensing receptor. Additionally, attempts to associate BMD with vitamin D status are complicated by the fact that BMD in adults is principally determined by attained peak bone mass that is partly dependent on vitamin D status (157). Thus, it is difficult to discern the relative importance of free vs. $25(\mathrm{OH}) \mathrm{D}$ in human cross-sectional studies using these parameters. As such, even when studies report statistically significant correlations, the $r$ values tend to fall in the range $(-0.3-0.1$ and $0.1-0.3)$ that are deemed "weak relationship" by statisticians. Second, many human studies do not employ subjects who are $25(\mathrm{OH}) \mathrm{D}$ deficient. These subjects would have the most to gain physiologically from treatment to return $25(\mathrm{OH}) \mathrm{D}$ in the serum to normal. Ideally, supplementation studies must include subjects that are clearly at insufficient levels and then have it demonstrably shown that their levels are raised into the sufficient range. It is through longer-term longitudinal analyses of intra-individual changes in serum total and free $25(\mathrm{OH}) \mathrm{D}$ after an aggressive vitamin $\mathrm{D}$ supplementation regimen that would have a greater likelihood to detect any associations.

Lastly, there is currently only one method of direct measurement of free $25(\mathrm{OH}) \mathrm{D}(90)$ with reasonable throughput. Though very promising, this assay is based on antibody interaction with $25(\mathrm{OH}) \mathrm{D}$ and needs further validation on the wide variety of sample quality (i.e., time from collection to testing, temperature of storage, variability of potentially interfering serum components among patients, etc.) encountered in clinical laboratory practice (158). In the future, perhaps a mass spectrometry-based method could be developed as is occurring in the measurement of other free hormones such as estradiol (159), thyroid hormone (160), and testosterone (161).

\section{AUTHOR CONTRIBUTIONS}

JA developed the overall organization of and approved this publication. JA, RC, AS, CG, and MH wrote sections of this review. VY and JW participated in copy editing.

\section{FUNDING}

This work was supported by NIH 5R01AR063910-05. 
6. Holick MF, Richtand NM, McNeill SC, Holick SA, Frommer JE, Henley JW, et al. Isolation and identification of previtamin D3 from the skin of rats exposed to ultraviolet irradiation. Biochemistry. (1979) 18:1003-8. doi: 10.1021/bi00573a011

7. Holick MF, MacLaughlin JA, Clark MB, Holick SA, Potts JT Jr, Anderson RR, et al. Photosynthesis of previtamin D3 in human skin and the physiologic consequences. Science. (1980) 210:203-5. doi: 10.1126/science.6251551

8. Holick MF, MacLaughlin JA, Doppelt SH. Regulation of cutaneous previtamin D3 photosynthesis in man: skin pigment is not an essential regulator. Science. (1981) 211:590-3. doi: 10.1126/science.6256855

9. Chen TC, Chimeh F, Lu Z, Mathieu J, Person KS, Zhang A, et al. Factors that influence the cutaneous synthesis and dietary sources of vitamin D. Arch Biochem Biophys. (2007) 460:213-7. doi: 10.1016/j.abb.2006.12.017

10. Bikle DD, Siiteri PK, Ryzen E, Haddad JG. Serum protein binding of 1,25-dihydroxyvitamin D: a reevaluation by direct measurement of free metabolite levels. J Clin Endocrinol Metab. (1985) 61:969-75. doi: 10.1210/jcem-61-5-969

11. Bikle DD, Gee E, Halloran B, Kowalski MA, Ryzen E, Haddad JG. Assessment of the free fraction of 25-hydroxyvitamin $\mathrm{D}$ in serum and its regulation by albumin and the vitamin D-binding protein. J Clin Endocrinol Metab. (1986) 63:954-9. doi: 10.1210/jcem-63-4-954

12. Cheng JB, Levine MA, Bell NH, Mangelsdorf DJ, Russell DW. Genetic evidence that the human CYP2R1 enzyme is a key vitamin D 25-hydroxylase. Proc Natl Acad Sci USA. (2004) 101:7711-5. doi: 10.1073/pnas.0402490101

13. Zhu JG, Ochalek JT, Kaufmann M, Jones G, Deluca HF. CYP2R1 is a major, but not exclusive, contributor to 25-hydroxyvitamin $\mathrm{D}$ production in vivo. Proc Natl Acad Sci USA. (2013) 110:15650-5. doi: 10.1073/pnas.1315006110

14. Avioli LV, Lee SW, McDonald JE, Lund J, DeLuca HF. Metabolism of vitamin D3-3H in human subjects: distribution in blood, bile, feces, and urine. J Clin Invest. (1967) 46:983-92. doi: 10.1172/JCI105605

15. Nykjaer A, Dragun D, Walther D, Vorum H, Jacobsen C, Herz J, et al. An endocytic pathway essential for renal uptake and activation of the steroid 25-(OH) vitamin D3. Cell. (1999) 96:507-15. doi: 10.1016/S0092-8674(00)80655-8

16. Jones G, Prosser DE, Kaufmann M. 25-Hydroxyvitamin D-24-hydroxylase (CYP24A1): its important role in the degradation of vitamin D. Arch Biochem Biophys. (2012) 523:9-18. doi: 10.1016/j.abb.2011.11.003

17. Kremer R, Goltzman D. Parathyroid hormone stimulates mammalian renal 25-hydroxyvitamin D3-1 alpha-hydroxylase in vitro. Endocrinology. (1982) 110:294-6. doi: 10.1210/endo-110-1-294

18. Murayama A, Takeyama K, Kitanaka S, Kodera Y, Hosoya T, Kato S. The promoter of the human 25-hydroxyvitamin D3 1 alpha-hydroxylase gene confers positive and negative responsiveness to $\mathrm{PTH}$, calcitonin, and 1 alpha,25(OH)2D3. Biochem Biophys Res Commun. (1998) 249:11-6. doi: $10.1006 /$ bbrc. 1998.9098

19. Tanaka Y, DeLuca HF. Measurement of mammalian 25-hydroxyvitamin D3 24R-and 1 alpha-hydroxylase. Proc Natl Acad Sci USA. (1981) 78:196-9. doi: 10.1073/pnas.78.1.196

20. Zierold C, Mings JA, DeLuca HF. Parathyroid hormone regulates 25hydroxyvitamin D(3)-24-hydroxylase mRNA by altering its stability. Proc Natl Acad Sci USA. (2001) 98:13572-6. doi: 10.1073/pnas.241516798

21. Shimada T, Kakitani M, Yamazaki Y, Hasegawa H, Takeuchi Y, Fujita T, et al. Targeted ablation of Fgf23 demonstrates an essential physiological role of FGF23 in phosphate and vitamin D metabolism. J Clin Invest. (2004) 113:561-8. doi: 10.1172/JCI19081

22. Shimada T, Hasegawa H, Yamazaki Y, Muto T, Hino R, Takeuchi Y, et al. FGF23 is a potent regulator of vitamin D metabolism and phosphate homeostasis. J Bone Miner Res. (2004) 19:429-35. doi: 10.1359/JBMR.0301264

23. Haussler MR, Whitfield GK, Kaneko I, Forster R, Saini R, Hsieh JC, et al. The role of vitamin D in the FGF23, klotho, and phosphate bone-kidney endocrine axis. Rev Endocr Metab Disord. (2012) 13:57-69. doi: 10.1007/s11154-011-9199-8

24. Haussler MR, Whitfield GK, Kaneko I, Haussler CA, Hsieh D, Hsieh JC, et al. Molecular mechanisms of vitamin D action. Calcif Tissue Int. (2013) 92:77-98. doi: 10.1007/s00223-012-9619-0

25. Holick MF. Vitamin D deficiency. N Engl J Med. (2007) 357:266-81. doi: 10.1056/NEJMra070553
26. Hewison M. Vitamin D and immune function: autocrine, paracrine or endocrine? Scand J Clin Lab Invest Suppl. (2012) 243:92-102. doi: $10.3109 / 00365513.2012 .682862$

27. Fuss M, Pepersack T, Gillet C, Karmali R, Corvilain J. Calcium and vitamin D metabolism in granulomatous diseases. Clin Rheumatol. (1992) 11:28-36. doi: 10.1007/BF02207080

28. Adams JS, Hewison M. Extrarenal expression of the 25-hydroxyvitamin D-1-hydroxylase. Arch Biochem Biophys. (2012) 523:95-102. doi: 10.1016/j.abb.2012.02.016

29. Liu PT, Stenger S, Li H, Wenzel L, Tan BH, Krutzik SR, et al. Toll-like receptor triggering of a vitamin $\mathrm{D}$-mediated human antimicrobial response. Science. (2006) 311:1770-3. doi: 10.1126/science.1123933

30. Adams JS, Ren S, Liu PT, Chun RF, Lagishetty V, Gombart AF, et al. Vitamin d-directed rheostatic regulation of monocyte antibacterial responses. $J$ Immunol. (2009) 182:4289-95. doi: 10.4049/jimmunol.0803736

31. Fabri M, Stenger S, Shin DM, Yuk JM, Liu PT, Realegeno S, et al. Vitamin $\mathrm{D}$ is required for IFN-gamma-mediated antimicrobial activity of human macrophages. Sci Transl Med. (2011) 3:104ra102. doi: 10.1126/scitranslmed.3003045

32. Adams JS, Ramin J, Rafison B, Windon C, Windon A, Liu PT. Redefining human vitamin D sufficiency: back to the basics. Bone Res. (2013) 1:2-10. doi: 10.4248/BR201301002

33. Jolliffe DA, Ganmaa D, Wejse C, Raqib R, Haq MA, Salahuddin $\mathrm{N}$, et al. Adjunctive vitamin $\mathrm{D}$ in tuberculosis treatment: metaanalysis of individual participant data. Eur Respir J. (2019) 53:1802003. doi: 10.1183/13993003.02003-2018

34. Krutzik SR, Hewison M, Liu PT, Robles JA, Stenger S, Adams JS, et al. IL-15 links TLR2/1-induced macrophage differentiation to the vitamin D-dependent antimicrobial pathway. J Immunol. (2008) 181:7115-20. doi: 10.4049/jimmunol.181.10.7115

35. Dinarello CA. The interleukin-1 family: 10 years of discovery. FASEB J. (1994) 8:1314-25. doi: 10.1096/fasebj.8.15.8001745

36. Oppenheim JJ, Biragyn A, Kwak LW, Yang D. Roles of antimicrobial peptides such as defensins in innate and adaptive immunity. Ann Rheum Dis. (2003) 62:ii17-21. doi: 10.1136/ard.62.suppl_2.ii17

37. Liu PT, Schenk M, Walker VP, Dempsey PW, Kanchanapoomi M, Wheelwright $\mathrm{M}$, et al. Convergence of IL-1beta and VDR activation pathways in human TLR2/1-induced antimicrobial responses. PLoS ONE. (2009) 4:e5810. doi: 10.1371/journal.pone.0005810

38. Koeffler HP, Reichel H, Bishop JE, Norman AW. gamma-Interferon stimulates production of 1,25-dihydroxyvitamin D3 by normal human macrophages. Biochem Biophys Res Commun. (1985) 127:596-603. doi: 10.1016/S0006-291X(85)80202-3

39. Bhalla AK, Amento EP, Clemens TL, Holick MF, Krane SM. Specific high-affinity receptors for 1,25-dihydroxyvitamin D3 in human peripheral blood mononuclear cells: presence in monocytes and induction in $\mathrm{T}$ lymphocytes following activation. J Clin Endocrinol Metab. (1983) 57:130810. doi: 10.1210/jcem-57-6-1308

40. Provvedini DM, Tsoukas CD, Deftos LJ, Manolagas SC. 1,25dihydroxyvitamin D3 receptors in human leukocytes. Science. (1983) 221:1181-3. doi: 10.1126/science.6310748

41. Jeffery LE, Burke F, Mura M, Zheng Y, Qureshi OS, Hewison M, et al. 1,25-Dihydroxyvitamin D3 and IL-2 combine to inhibit T cell production of inflammatory cytokines and promote development of regulatory $\mathrm{T}$ cells expressing CTLA-4 and FoxP3. J Immunol. (2009) 183:5458-67. doi: 10.4049/jimmunol.0803217

42. Kim DH, Sabour S, Sagar UN, Adams S, Whellan DJ. Prevalence of hypovitaminosis D in cardiovascular diseases (from the National Health and Nutrition Examination Survey 2001 to 2004). Am J Cardiol. (2008) 102:1540-4. doi: 10.1016/j.amjcard.2008.06.067

43. Kendrick J, Targher G, Smits G, Chonchol M. 25-Hydroxyvitamin D deficiency is independently associated with cardiovascular disease in the Third National Health and Nutrition Examination Survey. Atherosclerosis. (2009) 205:255-60. doi: 10.1016/j.atherosclerosis.2008.10.033

44. Manson JE, Cook NR, Lee IM, Christen W, Bassuk SS, Mora S, et al. Vitamin $\mathrm{D}$ supplements and prevention of cancer and cardiovascular disease. $N$ Engl J Med. (2019) 380:33-44. doi: 10.1056/NEJMoa1809944 
45. Ross AC, Manson JE, Abrams SA, Aloia JF, Brannon PM, Clinton SK, et al. The 2011 report on dietary reference intakes for calcium and vitamin $\mathrm{D}$ from the Institute of Medicine: what clinicians need to know. J Clin Endocrinol Metab. (2011) 96:53-8. doi: 10.1210/jc.2010-2704

46. Holick MF, Binkley NC, Bischoff-Ferrari HA, Gordon CM, Hanley DA, Heaney RP, et al. Evaluation, treatment, and prevention of vitamin D deficiency: an Endocrine Society clinical practice guideline. J Clin Endocrinol Metab. (2011) 96:1911-30. doi: 10.1210/jc.2011-0385

47. VitaminDCouncil I Tested My Vitamin D Level. What do my results mean? Available online at: https://www.vitamindcouncil.org/i-tested-my-vitamind-level-what-do-my-results-mean/\#.XDeU7i2ZNBw (accessed January 10, 2019).

48. SACN. SACN Vitamin D and Health Report (2016). Available online at: https://www.gov.uk/government/publications/sacn-vitamin-d-and-healthreport (accessed January 10, 2019).

49. Spiro A, Buttriss JL. Vitamin D: an overview of vitamin D status and intake in Europe. Nutr Bull. (2014) 39:322-50. doi: 10.1111/nbu.12108

50. Herrmann M, Farrell CL, Pusceddu I, Fabregat-Cabello N, Cavalier E. Assessment of vitamin D status-a changing landscape. Clin Chem Lab Med. (2017) 55:3-26. doi: 10.1515/cclm-2016-0264

51. Carlberg C, Haq A. The concept of the personal vitamin D response index. $J$ Steroid Biochem Mol Biol. (2018) 175:12-7. doi: 10.1016/j.jsbmb.2016.12.011

52. Jones G, Kaufmann M. Vitamin D metabolite profiling using liquid chromatography-tandem mass spectrometry (LC-MS/MS). J Steroid Biochem Mol Biol. (2016) 164:110-4. doi: 10.1016/j.jsbmb.2015.09.026

53. Sempos CT, Heijboer AC, Bikle DD, Bollerslev J, Bouillon R, Brannon PM, et al. Vitamin D assays and the definition of hypovitaminosis D: results from the First International Conference on Controversies in Vitamin D. Br J Clin Pharmacol. (2018) 84:2194-207. doi: 10.1111/bcp.13652

54. Chapuy MC, Preziosi P, Maamer M, Arnaud S, Galan P, Hercberg S, et al. Prevalence of vitamin D insufficiency in an adult normal population. Osteoporos Int. (1997) 7:439-43. doi: 10.1007/s001980050030

55. Holick MF, Siris ES, Binkley N, Beard MK, Khan A, Katzer JT, et al. Prevalence of vitamin D inadequacy among postmenopausal North American women receiving osteoporosis therapy. J Clin Endocrinol Metab. (2005) 90:3215-24. doi: 10.1210/jc.2004-2364

56. Fleet JC. The role of vitamin D in the endocrinology controlling calcium homeostasis. Mol Cell Endocrinol. (2017) 453:36-45. doi: 10.1016/j.mce.2017.04.008

57. Tebben PJ, Singh RJ, Kumar R. Vitamin D-mediated hypercalcemia: mechanisms, diagnosis, and treatment. Endocr Rev. (2016) 37:521-47. doi: 10.1210/er.2016-1070

58. Kream BE, Jose MJ, DeLuca HF. The chick intestinal cytosol binding protein for 1,25-dihydroxyvitamin D3: a study of analog binding. Arch Biochem Biophys. (1977) 179:462-8. doi: 10.1016/0003-9861(77)90134-5

59. Saramaki A, Diermeier S, Kellner R, Laitinen H, Vaisanen S, Carlberg C. Cyclical chromatin looping and transcription factor association on the regulatory regions of the p21 (CDKN1A) gene in response to 1alpha,25-dihydroxyvitamin D3. J Biol Chem. (2009) 284:8073-82. doi: 10.1074/jbc.M808090200

60. Pike JW. Genome-wide principles of gene regulation by the vitamin D receptor and its activating ligand. Mol Cell Endocrinol. (2011) 347:3-10. doi: 10.1016/j.mce.2011.05.012

61. Creo AL, Thacher TD, Pettifor JM, Strand MA, Fischer PR. Nutritional rickets around the world: an update. Paediatr Int Child Health. (2017) 37:84-98. doi: 10.1080/20469047.2016.1248170

62. Pettifor JM, Prentice A. The role of vitamin D in paediatric bone health. Best Pract Res Clin Endocrinol Metab. (2011) 25:573-84. doi: 10.1016/j.beem.2011.06.010

63. Malloy PJ, Feldman D. Genetic disorders and defects in vitamin d action. Endocrinol Metab Clin North Am. (2010) 39:333-46, table of contents. doi: 10.1016/j.ecl.2010.02.004

64. Munns CF, Shaw N, Kiely M, Specker BL, Thacher TD, Ozono K, et al. Global consensus recommendations on prevention and management of nutritional rickets. J Clin Endocrinol Metab. (2016) 101:394-415. doi: $10.1210 /$ jc. $2015-2175$

65. Silverberg SJ, Shane E, Dempster DW, Bilezikian JP. The effects of vitamin $\mathrm{D}$ insufficiency in patients with primary hyperparathyroidism.

\section{Am J Med. (1999) 107:561-7. doi: 10.1016/S0002-9343(99)00} 294-6

66. Boudou P, Ibrahim F, Cormier C, Sarfati E, Souberbielle JC. A very high incidence of low 25 hydroxy-vitamin D serum concentration in a French population of patients with primary hyperparathyroidism. J Endocrinol Invest. (2006) 29:511-5. doi: 10.1007/BF03344140

67. Priemel M, von Domarus C, Klatte TO, Kessler S, Schlie J, Meier S, et al. Bone mineralization defects and vitamin D deficiency: histomorphometric analysis of iliac crest bone biopsies and circulating 25-hydroxyvitamin D in 675 patients. J Bone Miner Res. (2010) 25:305-12. doi: 10.1359/jbmr.090728

68. Wagner D, Hanwell HE, Vieth R. An evaluation of automated methods for measurement of serum 25-hydroxyvitamin D. Clin Biochem. (2009) 42:1549-56. doi: 10.1016/j.clinbiochem.2009.07.013

69. Adams JS, Chen H, Chun RF, Nguyen L, Wu S, Ren SY, et al. Novel regulators of vitamin D action and metabolism: lessons learned at the Los Angeles zoo. J Cell Biochem. (2003) 88:308-14. doi: 10.1002/jcb.10333

70. Adams JS, Chen H, Chun R, Gacad MA, Encinas C, Ren S, et al. Response element binding proteins and intracellular vitamin $\mathrm{D}$ binding proteins: novel regulators of vitamin D trafficking, action and metabolism. J Steroid Biochem Mol Biol. (2004) 89-90:461-5. doi: 10.1016/j.jsbmb.2004.03.016

71. Shinki T, Shiina Y, Takahashi N, Tanioka Y, Koizumi H, Suda T. Extremely high circulating levels of 1 alpha,25-dihydroxyvitamin D3 in the marmoset, a new world monkey. Biochem Biophys Res Commun. (1983) 114:452-7. doi: 10.1016/0006-291X(83)90801-X

72. Adams JS, Gacad MA, Baker AJ, Kheun G, Rude RK. Diminished internalization and action of 1,25-dihydroxyvitamin D3 in dermal fibroblasts cultured from New World primates. Endocrinology. (1985) 116:2523-7. doi: 10.1210/endo-116-6-2523

73. Adams JS, Gacad MA. Phenotypic diversity of the cellular 1,25dihydroxyvitamin D3-receptor interaction among different genera of New World primates. J Clin Endocrinol Metab. (1988) 66:224-9. doi: 10.1210/jcem-66-1-224

74. Chun RF, Chen H, Boldrick L, Sweet C, Adams JS. Cloning, sequencing, and functional characterization of the vitamin $\mathrm{D}$ receptor in vitamin D-resistant New World primates. Am J Primatol. (2001) 54:107-18. doi: 10.1002/ajp.1016

75. Gacad MA, Adams JS. Endogenous blockade of 1,25-dihydroxyvitamin Dreceptor binding in New World primate cells. J Clin Invest. (1991) 87:9961001. doi: 10.1172/JCI115108

76. Gacad MA, Adams JS. Specificity of steroid binding in New World primate B95-8 cells with a vitamin D-resistant phenotype. Endocrinology. (1992) 131:2581-7. doi: 10.1210/endo.131.6.1446602

77. Gacad MA, Chen H, Arbelle JE, LeBon T, Adams JS. Functional characterization and purification of an intracellular vitamin D-binding protein in vitamin D-resistant new world primate cells. Amino acid sequence homology with proteins in the hsp-70 family. J Biol Chem. (1997) 272:8433-40. doi: 10.1074/jbc.272.13.8433

78. Gacad MA, Adams JS. Proteins in the heat shock-70 family specifically bind 25-hydroxyvitamin D3 and 17beta-estradiol. J Clin Endocrinol Metab. (1998) 83:1264-7. doi: 10.1210/jc.83.4.1264

79. Wu S, Chun R, Gacad MA, Ren S, Chen H, Adams JS. Regulation of 1,25dihydroxyvitamin d synthesis by intracellular vitamin d binding protein-1. Endocrinology. (2002) 143:4135. doi: 10.1210/en.2002-220568

80. Wu S, Ren S, Chen H, Chun RF, Gacad MA, Adams JS. Intracellular vitamin $\mathrm{D}$ binding proteins: novel facilitators of vitamin D-directed transactivation. Mol Endocrinol. (2000) 14:1387-97. doi: 10.1210/mend.14.9.0523

81. Chun R, Gacad MA, Hewison M, Adams JS. Adenosine 5' -triphosphatedependent vitamin $\mathrm{D}$ sterol binding to heat shock protein-70 chaperones. Endocrinology. (2005) 146:5540-4. doi: 10.1210/en.2005-0579

82. Chun RF, Gacad M, Nguyen L, Hewison M, Adams JS. Co-chaperone potentiation of vitamin $\mathrm{D}$ receptor-mediated transactivation: a role for $\mathrm{Bcl} 2$-associated athanogene-1 as an intracellular-binding protein for 1,25-dihydroxyvitamin D3. J Mol Endocrinol. (2007) 39:81-9. doi: 10.1677/JME-07-0042

83. Chun RF, Peercy BE, Adams JS, Hewison M. Vitamin D binding protein and monocyte response to 25-hydroxyvitamin D and 1,25-dihydroxyvitamin D: analysis by mathematical modeling. PLoS ONE. (2012) 7:e30773. doi: 10.1371/journal.pone.0030773 
84. Vermeulen A, Verdonck L, Kaufman JM. A critical evaluation of simple methods for the estimation of free testosterone in serum. J Clin Endocrinol Metab. (1999) 84:3666-72. doi: 10.1210/jcem.84.10.6079

85. Wilke TJ. A challenge of several concepts of free thyroxin index for assessing thyroid status in patients with altered thyroid-binding protein capacity. Clin Chem. (1983) 29:56-9.

86. Rosner W, Auchus RJ, Azziz R, Sluss PM, Raff H. Position statement: Utility, limitations, and pitfalls in measuring testosterone: an Endocrine Society position statement. J Clin Endocrinol Metab. (2007) 92:405-13. doi: $10.1210 /$ jc. $2006-1864$

87. van Deventer HE, Soldin SJ. The expanding role of tandem mass spectrometry in optimizing diagnosis and treatment of thyroid disease. $A d v$ Clin Chem. (2013) 61:127-52. doi: 10.1016/B978-0-12-407680-8.00005-1

88. Nielson CM, Jones KS, Chun RF, Jacobs JM, Wang Y, Hewison M, et al. Free 25-hydroxyvitamin D: impact of vitamin D binding protein assays on racial-genotypic associations. J Clin Endocrinol Metab. (2016) 101:2226-34. doi: $10.1210 /$ jc.2016-1104

89. Bikle DD, Gee E, Halloran B, Haddad JG. Free 1,25-dihydroxyvitamin D levels in serum from normal subjects, pregnant subjects, and subjects with liver disease. J Clin Invest. (1984) 74:1966-71. doi: 10.1172/JCI111617

90. Diasource Free 25OH Vitamin D ELISA. Available online at: https:// www.diasource-diagnostics.com/RUO-Products/ImmunoAssays/BoneMetabolism/Vitamin-D/Free-25OH-Vitamin-D-ELISA-96-tests (accessed March 15, 2019).

91. Berg AH, Bhan I, Powe C, Karumanchi SA, Xu D, Thadhani RI. Acute homeostatic changes following vitamin D2 supplementation. J Endocr Soc. (2017) 1:1135-49. doi: 10.1210/js.2017-00244

92. Chun RF. New perspectives on the vitamin D binding protein. Cell Biochem Funct. (2012) 30:445-56. doi: 10.1002/cbf.2835

93. Delanghe JR, Speeckaert R, Speeckaert MM. Behind the scenes of vitamin D binding protein: more than vitamin D binding. Best Pract Res Clin Endocrinol Metab. (2015) 29:773-86. doi: 10.1016/j.beem.2015.06.006

94. Rehder DS, Nelson RW, Borges CR. Glycosylation status of vitamin D binding protein in cancer patients. Protein Sci. (2009) 18:2036-42. doi: 10.1002 /pro. 214

95. Nagasawa H, Uto Y, Sasaki H, Okamura N, Murakami A, Kubo S, et al. Gc protein (vitamin D-binding protein): Gc genotyping and GcMAF precursor activity. Anticancer Res. (2005) 25:3689-95.

96. Ravnsborg T, Olsen DT, Thysen AH, Christiansen M, Houen G, Hojrup P. The glycosylation and characterization of the candidate Gc macrophage activating factor. Biochim Biophys Acta. (2010) 1804:909-17. doi: 10.1016/j.bbapap.2009.12.022

97. Hollis BW. Comparison of equilibrium and disequilibrium assay conditions for ergocalciferol, cholecalciferol and their major metabolites. J Steroid Biochem. (1984) 21:81-6. doi: 10.1016/0022-4731(84)90063-3

98. Van Baelen H, Bouillon R, De Moor P. Vitamin D-binding protein (Gcglobulin) binds actin. J Biol Chem. (1980) 255:2270-2.

99. Lee WM, Emerson DL, Werner PA, Arnaud P, Goldschmidt-Clermont P, Galbraith RM. Decreased serum group-specific component protein levels and complexes with actin in fulminant hepatic necrosis. Hepatology. (1985) 5:271-5. doi: 10.1002/hep.1840050220

100. Swamy N, Ray R. Fatty acid-binding site environments of serum vitamin Dbinding protein and albumin are different. Bioorg Chem. (2008) 36:165-8. doi: 10.1016/j.bioorg.2008.02.002

101. Kew RR, Webster RO. Gc-globulin (vitamin D-binding protein) enhances the neutrophil chemotactic activity of C5a and C5a des Arg. J Clin Invest. (1988) 82:364-9. doi: 10.1172/JCI113596

102. Svasti J, Kurosky A, Bennett A, Bowman BH. Molecular basis for the three major forms of human serum vitamin D binding protein (group-specific component). Biochemistry. (1979) 18:1611-7. doi: 10.1021/bi00575a036

103. Constans J, Cleve H. Group-specific component. Report on the First International Workshop, College de France-July 27-28, 1978-Paris. Hum Genet. (1979) 48:143-9. doi: 10.1007/BF00286897

104. Kamboh MI, Ferrell RE. Ethnic variation in vitamin D-binding protein (GC): a review of isoelectric focusing studies in human populations. Hum Genet. (1986) 72:281-93. doi: 10.1007/BF00290950

105. NCBI dbSNP Short Genetic Variations. Available online at: https://www.ncbi. nlm.nih.gov/snp/?term=GC (accessed January 10, 2019).
106. Arnaud J, Constans J. Affinity differences for vitamin D metabolites associated with the genetic isoforms of the human serum carrier protein (DBP). Hum Genet. (1993) 92:183-8. doi: 10.1007/BF00219689

107. Kawakami M, Imawari M, Goodman DS. Quantitative studies of the interaction of cholecalciferol (vitamin D3) and its metabolites with different genetic variants of the serum binding protein for these sterols. Biochem J. (1979) 179:413-23. doi: 10.1042/bj1790413

108. Bouillon R, van Baelen $\mathrm{H}$, de Moor P. Comparative study of the affinity of the serum vitamin D-binding protein. J Steroid Biochem. (1980) 13:1029-34. doi: 10.1016/0022-4731(80)90133-8

109. Boutin B, Galbraith RM, Arnaud P. Comparative affinity of the major genetic variants of human group-specific component (vitamin D-binding protein) for 25-(OH) vitamin D. J Steroid Biochem. (1989) 32:59-63. doi: 10.1016/0022-4731(89)90014-9

110. Chun RF, Lauridsen AL, Suon L, Zella LA, Pike JW, Modlin RL, et al. Vitamin D-binding protein directs monocyte responses to 25-hydroxyand 1,25-dihydroxyvitamin D. J Clin Endocrinol Metab. (2010) 95:3368-76. doi: 10.1210/jc.2010-0195

111. Jeffery LE, Wood AM, Qureshi OS, Hou TZ, Gardner D, Briggs Z, et al. Availability of 25-hydroxyvitamin $\mathrm{D}(3)$ to APCs controls the balance between regulatory and inflammatory $\mathrm{T}$ cell responses. J Immunol. (2012) 189:5155-64. doi: 10.4049/jimmunol.1200786

112. Kongsbak M, von Essen MR, Levring TB, Schjerling P, Woetmann A, Odum $\mathrm{N}$, et al. Vitamin D-binding protein controls $\mathrm{T}$ cell responses to vitamin $\mathrm{D}$. BMC Immunol. (2014) 15:35. doi: 10.1186/s12865-014-0035-2

113. Schwartz JB, Gallagher JC, Jorde R, Berg V, Walsh J, Eastell R, et al. Determination of Free 25(OH)D concentrations and their relationships to total 25(OH)D in multiple clinical populations. J Clin Endocrinol Metab. (2018) 103:3278-88. doi: 10.1210/jc.2018-00295

114. Powe CE, Evans MK, Wenger J, Zonderman AB, Berg AH, Nalls $\mathrm{M}$, et al. Vitamin D-binding protein and vitamin D status of black Americans and white Americans. N Engl J Med. (2013) 369:1991-2000. doi: 10.1056/NEJMoa1306357

115. Denburg MR, Hoofnagle AN, Sayed S, Gupta J, de Boer IH, Appel LJ, et al. Comparison of two ELISA methods and mass spectrometry for measurement of vitamin D-binding protein: implications for the assessment of bioavailable vitamin D concentrations across genotypes. J Bone Miner Res. (2016) 31:1128-36. doi: 10.1002/jbmr.2829

116. Lauridsen AL, Vestergaard P, Nexo E. Mean serum concentration of vitamin $\mathrm{D}$-binding protein ( $\mathrm{Gc}$ globulin) is related to the Gc phenotype in women. Clin Chem. (2001) 47:753-6.

117. Schwartz JB, Lai J, Lizaola B, Kane L, Markova S, Weyland P, et al A comparison of measured and calculated free $25(\mathrm{OH})$ vitamin D levels in clinical populations. J Clin Endocrinol Metab. (2014) 99:1631-7. doi: $10.1210 /$ jc. $2013-3874$

118. Henderson CM, Fink SL, Bassyouni H, Argiropoulos B, Brown L, Laha TJ, et al. Vitamin D-binding protein deficiency and homozygous deletion of the GC gene. N Engl J Med. (2019) 380:1150-7. doi: 10.1056/NEJMoa1807841

119. Safadi FF, Thornton P, Magiera H, Hollis BW, Gentile M, Haddad JG, et al. Osteopathy and resistance to vitamin D toxicity in mice null for vitamin D binding protein. J Clin Invest. (1999) 103:239-51. doi: 10.1172/JCI5244

120. Zella LA, Shevde NK, Hollis BW, Cooke NE, Pike JW. Vitamin D-binding protein influences total circulating levels of 1,25-dihydroxyvitamin D3 but does not directly modulate the bioactive levels of the hormone in vivo. Endocrinology. (2008) 149:3656-67. doi: 10.1210/en.2008-0042

121. Chun RF, Hernandez I, Pereira R, Swinkles L, Huijs T, Zhou R, et al. Differential responses to vitamin D2 and vitamin D3 are associated with variations in free 25-hydroxyvitamin D. Endocrinology. (2016) 157:3420-30. doi: 10.1210/en.2016-1139

122. Southworth LO, Holick MF, Chen TC, Kunz TH. Effects of sunlight on behavior and 25-hydroxyvitamin D levels in two species of Old World fruit bats. Dermatoendocrinology. (2013) 5:192-8. doi: 10.4161/derm.24020

123. Vieth R, Kessler MJ, Pritzker KP. Species differences in the binding kinetics of 25-hydroxyvitamin D3 to vitamin D binding protein. Can J Physiol Pharmacol. (1990) 68:1368-71. doi: 10.1139/y90-207

124. Adams JS, Hewison M. Unexpected actions of vitamin D: new perspectives on the regulation of innate and adaptive immunity. Nat Clin Pract Endocrinol Metab. (2008) 4:80-90. doi: 10.1038/ncpendmet0716 
125. Yu C, Xue H, Wang L, Chen Q, Chen X, Zhang Y, et al. Serum bioavailable and free 25-hydroxyvitamin D levels, but not its total level, are associated with the risk of mortality in patients with coronary artery disease. Circ Res. (2018) 123:996-1007. doi: 10.1161/CIRCRESAHA.118.313558

126. Strisciuglio C, Cenni S, Giugliano FP, Miele E, Cirillo G, Martinelli M, et al. The role of inflammation on vitamin $\mathrm{D}$ levels in a cohort of pediatric patients with inflammatory bowel disease. J Pediatr Gastroenterol Nutr. (2018) 67:501-6. doi: 10.1097/MPG.0000000000002049

127. Sauer CG, Loop MS, Venkateswaran S, Tangpricha V, Ziegler TR, Dhawan A, et al. Free and bioavailable 25-hydroxyvitamin D concentrations are associated with disease activity in pediatric patients with newly diagnosed treatment naive ulcerative colitis. Inflamm Bowel Dis. (2018) 24:641-50. doi: 10.1093/ibd/izx052

128. Lee CC, Young KA, Norris JM, Rotter JI, Liu Y, Lorenzo C, et al. Association of directly measured plasma free $25(\mathrm{OH}) \mathrm{D}$ with insulin sensitivity and secretion: the IRAS Family Study. J Clin Endocrinol Metab. (2017) 102:2781-8. doi: 10.1210/jc.2017-00039

129. Kane L, Moore K, Lutjohann D, Bikle D, Schwartz JB. Vitamin D3 effects on lipids differ in statin and non-statin-treated humans: superiority of free 25-OH D levels in detecting relationships. J Clin Endocrinol Metab. (2013) 98:4400-9. doi: 10.1210/jc.2013-1922

130. Altinova AE, Ozkan C, Akturk M, Gulbahar O, Yalcin M, Cakir N, et al. Vitamin D-binding protein and free vitamin $\mathrm{D}$ concentrations in acromegaly. Endocrine. (2016) 52:374-9. doi: 10.1007/s12020-015-0789-1

131. Lima JJ, Castro M, King TS, Lang JE, Ortega VE, Peters SP, et al. Association of free vitamin D3 concentrations and asthma treatment failures in the VIDA Trial. Ann Allergy Asthma Immunol. (2018) 121:444-450 e441. doi: 10.1016/j.anai.2018.06.001

132. Andersen SW, Shu XO, Cai Q, Khankari NK, Steinwandel MD, Jurutka PW, et al. Total and free circulating vitamin D and vitamin D-binding protein in relation to colorectal cancer risk in a prospective study of African Americans. Cancer Epidemiol Biomarkers Prev. (2017) 26:1242-7. doi: 10.1158/1055-9965.EPI-17-0133

133. Powe CE, Ricciardi C, Berg AH, Erdenesanaa D, Collerone G, Ankers E, et al. Vitamin D-binding protein modifies the vitamin D-bone mineral density relationship. J Bone Miner Res. (2011) 26:1609-16. doi: 10.1002/jbmr.387

134. Bhan I, Powe CE, Berg AH, Ankers E, Wenger JB, Karumanchi SA, et al. Bioavailable vitamin D is more tightly linked to mineral metabolism than total vitamin D in incident hemodialysis patients. Kidney Int. (2012) 82:84-9. doi: 10.1038/ki.2012.19

135. RङDBiosystems Improved Sensitivity of Vitamin D BP ELISA Kits. Available online at: https:/www.rndsystems.com/product-highlight/improvedsensitivity-vitamin-d-bp-elisa-kits (accessed March 27, 2019).

136. Aloia J, Dhaliwal R, Mikhail M, Shieh A, Stolberg A, Ragolia L, et al. Free $25(\mathrm{OH}) \mathrm{D}$ and calcium absorption, PTH, and markers of bone turnover. $J$ Clin Endocrinol Metab. (2015) 100:4140-5. doi: 10.1210/jc.2015-2548

137. Peris P, Filella X, Monegal A, Guanabens N, Foj L, Bonet M, et al. Comparison of total, free and bioavailable 25-OH vitamin $\mathrm{D}$ determinations to evaluate its biological activity in healthy adults: the LabOscat study. Osteoporos Int. (2017) 28:2457-64. doi: 10.1007/s00198-017-4062-8

138. Walsh JS, Evans AL, Bowles S, Naylor KE, Jones KS, Schoenmakers I, et al. Free 25-hydroxyvitamin $\mathrm{D}$ is low in obesity, but there are no adverse associations with bone health. Am J Clin Nutr. (2016) 103:1465-71. doi: 10.3945/ajcn.115.120139

139. Lai JC, Bikle DD, Lizaola B, Hayssen H, Terrault NA, Schwartz JB. Total $25(\mathrm{OH})$ vitamin $\mathrm{D}$, free $25(\mathrm{OH})$ vitamin $\mathrm{D}$ and markers of bone turnover in cirrhotics with and without synthetic dysfunction. Liver Int. (2015) 35:2294-300. doi: 10.1111/liv.12819

140. Lopez-Molina M, Santillan C, Murillo M, Valls A, Bosch L, Bel $\mathrm{J}$, et al. Measured free 25-hydroxyvitamin $\mathrm{D}$ in healthy children and relationship to total 25-hydroxyvitamin D, calculated free 25hydroxyvitamin D and vitamin D binding protein. Clin Biochem. (2018) 61:23-7. doi: 10.1016/j.clinbiochem.2018.08.007

141. Alzaman NS, Dawson-Hughes B, Nelson J, D’Alessio D, Pittas AG. Vitamin $\mathrm{D}$ status of black and white Americans and changes in vitamin D metabolites after varied doses of vitamin D supplementation. Am J Clin Nutr. (2016) 104:205-14. doi: 10.3945/ajcn.115.129478
142. Sollid ST, Hutchinson MY, Berg V, Fuskevag OM, Figenschau Y, Thorsby $\mathrm{PM}$, et al. Effects of vitamin D binding protein phenotypes and vitamin D supplementation on serum total $25(\mathrm{OH}) \mathrm{D}$ and directly measured free 25(OH)D. Eur J Endocrinol. (2016) 174:445-52. doi: 10.1530/EJE-15-1089

143. Tsuprykov O, Buse C, Skoblo R, Haq A, Hocher B. Reference intervals for measured and calculated free 25-hydroxyvitamin D in normal pregnancy. $J$ Steroid Biochem Mol Biol. (2018) 181:80-7. doi: 10.1016/j.jsbmb.2018.03.005

144. Schwartz JB, Kane L, Bikle D. Response of vitamin D concentration to vitamin D3 administration in older adults without sun exposure: a randomized double-blind trial. J Am Geriatr Soc. (2016) 64:65-72. doi: 10.1111 /jgs. 13774

145. Shieh A, Chun RF, Ma C, Witzel S, Meyer B, Rafison B, et al. Effects of high-dose vitamin D2 versus D3 on total and free 25-hydroxyvitamin D and markers of calcium balance. J Clin Endocrinol Metab. (2016) 101:3070-8. doi: 10.1210/jc.2016-1871

146. Shieh A, Ma C, Chun RF, Wittwer-Schegg J, Swinkels L, Huijs T, et al. Associations between change in total and free 25-hydroxyvitamin D with 24,25-dihydroxyvitamin D and parathyroid hormone. J Clin Endocrinol Metab. (2018) 103:3368-75. doi: 10.1210/jc.2018-00515

147. Wang X, Shapses SA, Al-Hraishawi H. Free and bioavailable 25hydroxyvitamin D levels in patients with primary hyperparathyroidism. Endocr Pract. (2017) 23:66-71. doi: 10.4158/EP161434.OR

148. Szabo B, Tabak AG, Toldy E, Szekeres L, Szili B, Bakos B, et al. The role of serum total and free 25-hydroxyvitamin D and PTH values in defining vitamin D status at the end of winter: a representative survey. J Bone Miner Metab. (2017) 35:83-90. doi: 10.1007/s00774-015-0729-4

149. Gopal-Kothandapani JS, Evans LF, Walsh JS, Gossiel F, Rigby AS, Eastell $\mathrm{R}$, et al. Effect of vitamin D supplementation on free and total vitamin D: a comparison of Asians and Caucasians. Clin Endocrinol (Oxf). (2019) 90:222-31. doi: 10.1111/cen.13825

150. Best CM, Pressman EK, Queenan RA, Cooper E, O’Brien KO. Longitudinal changes in serum vitamin D binding protein and free 25-hydroxyvitamin D in a multiracial cohort of pregnant adolescents. J Steroid Biochem Mol Biol. (2018) 186:79-88. doi: 10.1016/j.jsbmb.2018.09.019

151. Jemielita TO, Leonard MB, Baker J, Sayed S, Zemel BS, Shults J, et al. Association of 25-hydroxyvitamin D with areal and volumetric measures of bone mineral density and parathyroid hormone: impact of vitamin D-binding protein and its assays. Osteoporos Int. (2016) 27:617-26. doi: 10.1007/s00198-015-3296-6

152. Alwan A, Rizkallah M, Maalouf G, Matta J, Frenn F, Berro AJ, et al. Positive correlations between free vitamin $\mathrm{D}$ and bone variables in a group of young Lebanese men. J Clin Densitom. (2018) 21:459-61. doi: 10.1016/j.jocd.2018.02.001

153. Michaelsson K, Rasmusson A, Wolk A, Byberg L, Mitchell A, Melhus H. The free hormone hypothesis: is free serum 25-hydroxyvitamin D a better marker for bone mineral density in older women? JBMR Plus. (2018) 2:367-74. doi: $10.1002 / \mathrm{jbm} 4.10059$

154. Segersten U, Correa P, Hewison M, Hellman P, Dralle H, Carling T, et al. 25-hydroxyvitamin $\mathrm{D}$ (3)-1alpha-hydroxylase expression in normal and pathological parathyroid glands. J Clin Endocrinol Metab. (2002) 87:2967-72. doi: 10.1210/jcem.87.6.8604

155. Ritter CS, Armbrecht HJ, Slatopolsky E, Brown AJ. 25-Hydroxyvitamin D(3) suppresses PTH synthesis and secretion by bovine parathyroid cells. Kidney Int. (2006) 70:654-9. doi: 10.1038/sj.ki.5000394

156. Ritter CS, Brown AJ. Direct suppression of Pth gene expression by the vitamin D prohormones doxercalciferol and calcidiol requires the vitamin D receptor. J Mol Endocrinol. (2011) 46:63-6. doi: 10.1677/JME-10-0128

157. Weaver CM, Gordon CM, Janz KF, Kalkwarf HJ, Lappe JM, Lewis R, et al. The National Osteoporosis Foundation's position statement on peak bone mass development and lifestyle factors: a systematic review and implementation recommendations. Osteoporos Int. (2016) 27:1281-386. doi: 10.1007/s00198-015-3440-3

158. Malmstroem S, Rejnmark L, Imboden JB, Shoback DM, Bikle DD. Current assays to determine free 25-hydroxyvitamin D in serum. J AOAC Int. (2017) 100:1323-7. doi: 10.5740/jaoacint.17-0085

159. Ray JA, Kushnir MM, Bunker A, Rockwood AL, Meikle AW. Direct measurement of free estradiol in human serum by equilibrium dialysis-liquid 
chromatography-tandem mass spectrometry and reference intervals of free estradiol in women. Clin Chim Acta. (2012) 413:1008-14. doi: $10.1016 /$ j.cca.2012.02.028

160. Welsh KJ, Soldin SJ. Diagnosis of endocrine disease: how reliable are free thyroid and total T3 hormone assays? Eur J Endocrinol. (2016) 175:R255-63. doi: 10.1530/EJE-16-0193

161. Fiers T, Wu F, Moghetti P, Vanderschueren D, Lapauw B, Kaufman JM. Reassessing free-testosterone calculation by liquid chromatographytandem mass spectrometry direct equilibrium dialysis. $J$ Clin Endocrinol Metab. (2018) 103:2167-74. doi: 10.1210/jc.201702360
Conflict of Interest: The authors declare that the research was conducted in the absence of any commercial or financial relationships that could be construed as a potential conflict of interest.

Copyright (๑ 2019 Chun, Shieh, Gottlieb, Yacoubian, Wang, Hewison and Adams. This is an open-access article distributed under the terms of the Creative Commons Attribution License (CC BY). The use, distribution or reproduction in other forums is permitted, provided the original author(s) and the copyright owner(s) are credited and that the original publication in this journal is cited, in accordance with accepted academic practice. No use, distribution or reproduction is permitted which does not comply with these terms. 